\title{
Oak Ridge National Laboratory Analysis of Waste Isolation Pilot Plant Samples: Integrated Summary Report
}

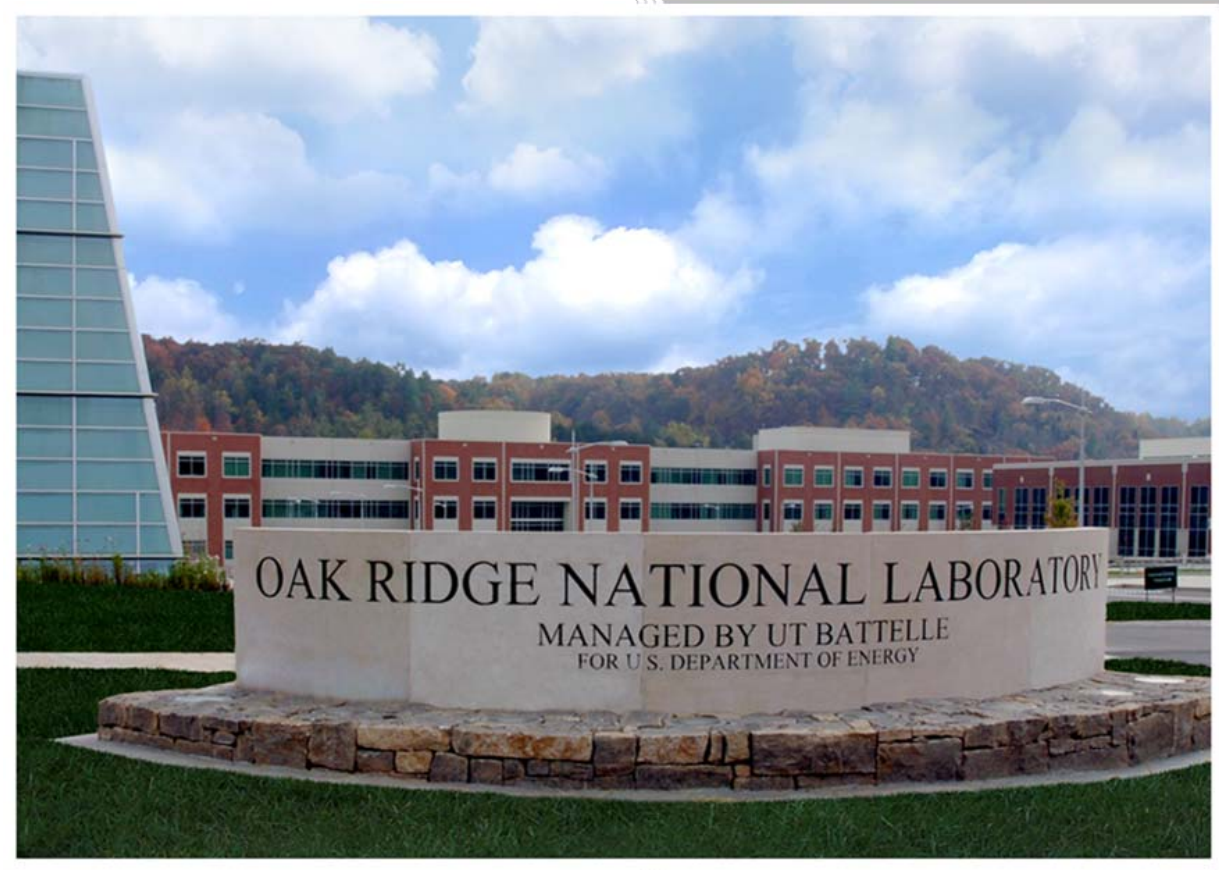

Approved for public release. Distribution is unlimited. 


\title{
DOCUMENT AVAILABILITY
}

Reports produced after January 1, 1996, are generally available free via US Department of Energy (DOE) SciTech Connect.

\section{Website http://www.osti.gov/scitech/}

Reports produced before January 1, 1996, may be purchased by members of the public from the following source:

\author{
National Technical Information Service \\ 5285 Port Royal Road \\ Springfield, VA 22161 \\ Telephone 703-605-6000 (1-800-553-6847) \\ TDD 703-487-4639 \\ Fax 703-605-6900 \\ E-mail info@ntis.gov \\ Website http://www.ntis.gov/help/ordermethods.aspx
}

Reports are available to DOE employees, DOE contractors, Energy Technology Data Exchange representatives, and International Nuclear Information System representatives from the following source:

Office of Scientific and Technical Information

PO Box 62

Oak Ridge, TN 37831

Telephone 865-576-8401

Fax 865-576-5728

E-mail reports@osti.gov

Website http://www.osti.gov/contact.html

This report was prepared as an account of work sponsored by an agency of the United States Government. Neither the United States Government nor any agency thereof, nor any of their employees, makes any warranty, express or implied, or assumes any legal liability or responsibility for the accuracy, completeness, or usefulness of any information, apparatus, product, or process disclosed, or represents that its use would not infringe privately owned rights. Reference herein to any specific commercial product, process, or service by trade name, trademark, manufacturer, or otherwise, does not necessarily constitute or imply its endorsement, recommendation, or favoring by the United States Government or any agency thereof. The views and opinions of authors expressed herein do not necessarily state or reflect those of the United States Government or any agency thereof. 


\title{
LETTER REPORT
}

\section{Analysis of Waste Isolation Pilot Plant Samples: Integrated Summary Report}

\author{
Phillip F. Britt \\ Chemical Sciences Division, Oak Ridge National Laboratory
}

March 2015

Prepared for the

U.S. Department of Energy

under contract DE-AC05-00OR22725

Prepared by

Oak Ridge National Laboratory

P. O. Box 2008

Oak Ridge, Tennessee 37831-6170

managed by

UT-BATTELLE, LLC 


\section{ACKNOWLEDGMENTS}

The author of this report would like to thank all of the individuals who contributed to the analysis of the samples taken from the Waste Isolation Pilot Plant (WIPP) near Carlsbad, New Mexico in support of the WIPP Technical Assessment Team (TAT) activities to determine to the extent feasible the mechanisms and chemical reactions that may have resulted in the breach of at least one waste drum and release of waste material in WIPP Panel 7 Room 7 on February 14, 2014. This report integrates and summarizes the results contained in three separate reports, described below, and draws conclusions based on those results.

- Chemical and Radiochemical Analyses of WIPP Samples R-15 C5 SWB and R16 C-4 Lip; PNNL24003, Pacific Northwest National Laboratory, December 2014

- Analysis of Waste Isolation Pilot Plant (WIPP) Underground and MgO Samples by the Savannah River National Laboratory (SRNL); SRNL-STI-2014-00617; Savannah River National Laboratory, December 2014

- $\quad$ Report for WIPP UG Sample \#3, R15C5 (9/3/14); LLNL-TR-667015; Lawrence Livermore National Laboratory, January 2015

This report is also contained in the Waste Isolation Pilot Plant Technical Assessment Team Report; SRNL-RP-2015-01198; Savannah River National Laboratory, March 17, 2015, as Appendix C: Analysis Integrated Summary Report.

The author would also like to acknowledge the leadership, guidance, and technical input of the members of the Waste Isolation Pilot Plant Technical Assessment Team (WIPP TAT), which includes David L. Wilson, Savannah River National Laboratory; Bradley R. Hart, Lawrence Livermore National Laboratory; Michael L. Baker, Oak Ridge National Laboratory; Jon M. Schwantes, Pacific Northwest National Laboratory; Paul E. Shoemaker, Sandia National Laboratory, and the TAT Technical Advisors, John E. Marra and Dwight E. Adams. Finally, the author would especially like to thank the analytical leads from PNNL, Jon Schwantes, and SRNL, Clint Gregory and John Young, for their leadership, insights and constant support, which was critical to the success of this effort. 


\section{CONTENTS}

TITLE PAGE

...iii

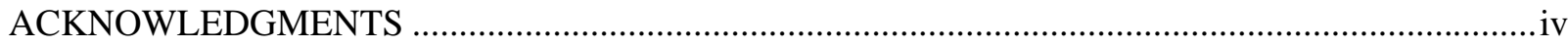

CONTENTS

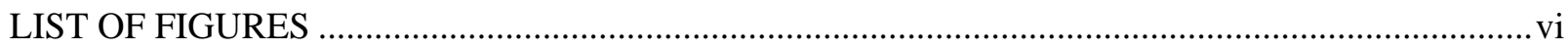

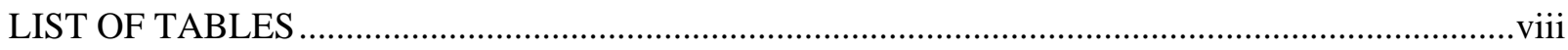

LIST OF ABBREVIATIONS AND ACRONYMS ...........................................................................ix

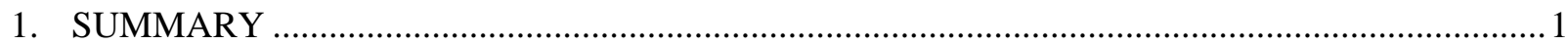

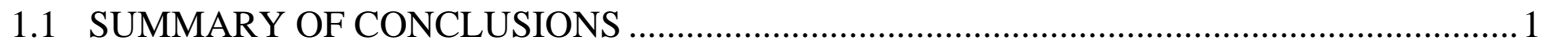

1.2 SUMMARY OF ANALYTICAL PROCESS …................................................................

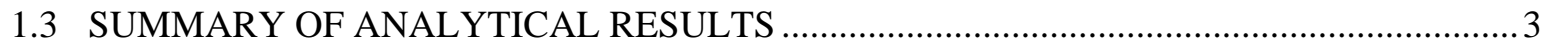

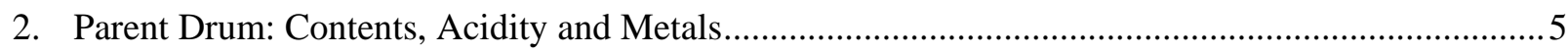

2.1 Acidity of Parent Drum (S855793)...................................................................................... 5

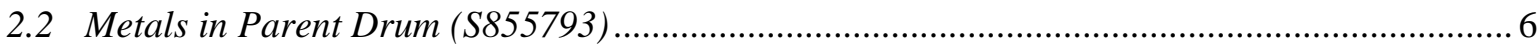

3. Exothermic Oxidation of Organics by Nitrate Salts ...............................................................

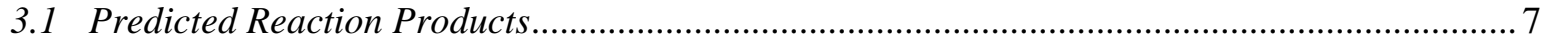

3.2 Optical and Electron Microscopy of WIPP Samples ......................................................... 10

3.3 Glovebox Glove Did Not Participate in the Oxidations Reactions ......................................... 14

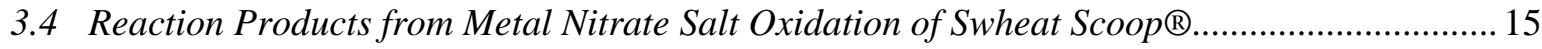

3.5 Reactions Inside 68660 Did Not Go to Completion ............................................................. 16

3.6 Oxidation Products Found in Debris but Nitration Products Were Not Detected....................18

3.7 No Products from Decomposition of TEAN Were Observed................................................... 23

3.8 Low Melting Eutectic Mixture of Salts Could Form .......................................................... 23

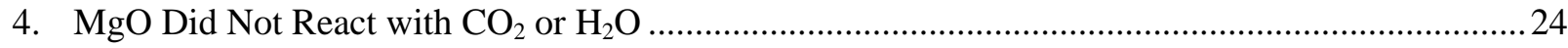

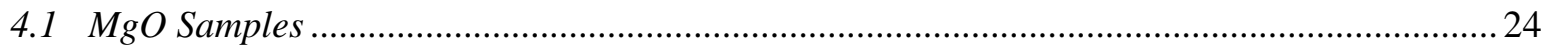

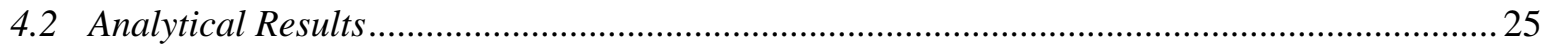

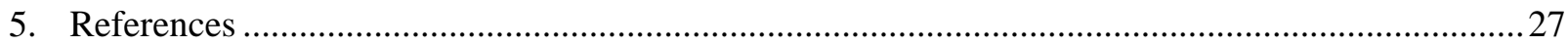




\section{LIST OF FIGURES}

Figure 1 SEM (A) and EDS (B) analysis of the debris from the parent drum...... 6

Figure 2 (a) Particle under white light and a 10x objective, (b) Particle illuminated by an excitation band of 375-425 $\mathrm{nm}$ observing the emission of $475 \mathrm{~nm}$ and longer. (c) The emission spectra of particle (blue) overlaid with the typical kitty litter (red)

Figure 3 Optical microscopy of R15 C5 particles 11

Figure $4 \quad$ Optical microscopy of R15 C5 particles 11

Figure 5 (a) SEM image of particles collected from R15 C5 and (b) Representative EDS of sample. 11

Figure 6 (a) SEM of small particles from R15 C5 and (b) EDS of particles. 11

Figure $7 \quad$ Elongated piece of steel from the sample collected from the lip of R16 C4. 12

Figure 8 Polarized light microscopy image of (a) salt-like particles from R15 C5 and (b) “hairy” particle from R15 C5 12

Figure 9 SEM analysis of salt particles from R16 C4............................................................13

Figure 10 SEM-EDS of small Pu particle associated with hairy salt particle from R16 C4...... 13

Figure 11 SEM-EDS of small particle of $\mathrm{Pb}$ associated with the hairy salt particle from $R 16$ C4 14

Figure 12 Radiograph of trash layer in drum 68660 showing the glovebox glove 14

Figure 13 SEM-EDS analysis of sample from the lip of R16 C4 showing a bismuth particle 15

Figure $14 \quad X R D$ analysis of the R15 C5 sample 16

Figure 15 TG-MS analysis of debris from R15 C5 under argon. 17

Figure 16 MS analysis of the evolved gases from the decomposition of R15 C5 under argon. 18

Figure 17 FTIR spectra of the solid R15 C5 sample compared to Swheat Scoop ${ }^{\circledR}$... 19

Figure 18 (a) Pictures of where ATR-IR data was collected on black particle 4 (blue dot) and black particle 5 (red dot) in subsample R16 C4. (b) Overview picture of subsample R16 C4, loose powder that was collected from the Swiffer sampler that was landed near the lip of the drum that ruptured (R16 C4). (c) IR spectra of black particle 4 (blue) and black particle 5 (red).

Figure 19 FTIR spectra of cellulose (chromatography paper) and nitrocellulose at room temperature [Coatas, 2014]

Figure 20 FTIR of the $\mathrm{CH}_{2} \mathrm{Cl}_{2}$ extract of $\mathrm{R} 15 \mathrm{C5}$. 21 
Figure 21 FTIR spectrum of a particle collected from the methylene chloride extract of R15 C5 compared to cellulose and Swheat Scoop ${ }^{\circledR}$. Particle is similar to cellulose. 22

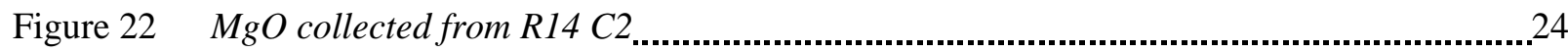

Figure 23 Sample collected from R16 C4 using Swiffer head ......................................................24

Figure $24 \quad \mathrm{MgO}$ sample collected from super sack in Panel 7 Room 7 ............................................25

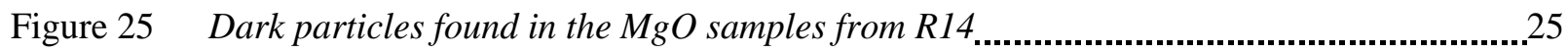

Figure $26 \quad X R D$ of $\mathrm{MgO}$ from R14 C2, R14 C4 and a reference $\mathrm{MgO}$ sample..................................25

Figure $27 \quad \mathrm{XRD}$ of $\mathrm{MgO}$ from super sack sampled at the surface ...............................................26

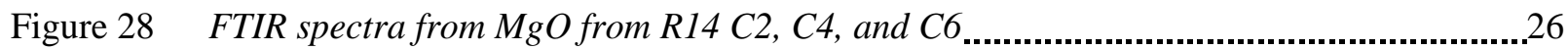

Figure 29 FTIR spectrum of $\mathrm{MgO}$ from sack at face of Panel 7 Room 7 ..........................................26 


\section{LIST OF TABLES}

Table 1 Composition of salts in 68660 (as described in the Cookoff Model Section). 5

Table 2 DSC data for reaction between lignocellulosics and various nitrate salts [Wu, 1986] 8

Table 3 Ratio of metal cations relative to sodium from the debris on R15 C5 and the parent drum 


\section{LIST OF ABBREVIATIONS AND ACRONYMS}

\begin{tabular}{|c|c|}
\hline CAM & continuous air monitor \\
\hline $\mathrm{COC}$ & Chain of Custody \\
\hline DOE & Department of Energy \\
\hline DSC & differential scanning calorimetry \\
\hline DTA & differential thermal analysis \\
\hline EDS & energy-dispersive spectroscopy \\
\hline FAS & fixed air sampler \\
\hline FTIR & Fourier transform infrared [spectroscopy] \\
\hline GC-MS & gas chromatograph-mass spectrometry \\
\hline IAEA & International Atomic Energy Agency \\
\hline IC & ion chromatography \\
\hline ICP-MS & inductively coupled plasma-mass spectrometry \\
\hline ICP-OES & inductively coupled plasma-optical emission spectroscopy \\
\hline LANL & Los Alamos National Laboratory \\
\hline LC-MS & liquid chromatography-mass spectrometry \\
\hline LLNL & Lawrence Livermore National Laboratory \\
\hline NMR & nuclear magnetic resonance \\
\hline ORNL & Oak Ridge National Laboratory \\
\hline PNNL & Pacific Northwest National Laboratory \\
\hline ppm & parts per million \\
\hline PVC & polyvinyl chloride \\
\hline R16 C4 & Row 16 Column 4 \\
\hline RTR & Real Time Radiography/Radiograph \\
\hline SEM-EDS & scanning electron microscopy-energy dispersive spectroscopy \\
\hline SRNL & Savannah River National Laboratory \\
\hline SWB & standard waste box \\
\hline TAA & Technical Assessment Area \\
\hline TAT & Technical Assessment Team \\
\hline TGA & thermogravimetric analysis \\
\hline TG/DTA & thermogravimetric and differential thermal analysis \\
\hline TEA & triethanolamine \\
\hline TEAN & triethanolammonium nitrate \\
\hline TG-MS & thermogravimetric-mass spectroscopy analysis \\
\hline WIPP & Waste Isolation Pilot Plant \\
\hline XRD & x-ray diffraction (micro-XRD) \\
\hline $\mathrm{XRF}$ & x-ray fluorescence (micro-XRF) \\
\hline
\end{tabular}




\section{ANALYSIS OF WASTE ISOLATION PILOT PLANT SAMPLES: INTEGRATED SUMMARY REPORT}

\section{SUMMARY}

\subsection{SUMMARY OF CONCLUSIONS}

Nondestructive and destructive analytical methods were used to analyze samples of debris collected from the top of R15 C5, the lip of R16 C4, the parent drum, and the continuous air monitor (CAM) and fixed air sampler (FAS) filters in addition to MgO samples collected from the tops of R14 C2, R14 C4, R14 C6 and R16 C4. The analytical evidence supports the conclusion that an exothermic oxidation reaction of Swheat Scoop ${ }^{\circledR}$ by metal nitrate salts produced sufficient quantities of gas to breach drum 68660 . The metals and the acidic environment found in drum 68660 are known to accelerate these oxidation reactions. Moreover, the ratio of metal nitrate salts in drum 68660 was in a range in which a low melting eutectic mixture could form, which would also accelerate the oxidation reactions. Nitrated organics were not detected and they are not necessary to produce the exothermic reaction leading to the breach of drum 68660. All the contents of the drum were not consumed and the material ejected from drum 68660 either did not experience temperatures over $200^{\circ} \mathrm{C}$, or their exposure to elevated temperatures was very limited in duration (<seconds). These findings are based on the details described below.

- Metals and acid were present that would accelerate the oxidation reactions:

o The metals found in the debris and the acidic environment of drum 68660 are known to accelerate the decompostion of the organic materials comprising the Swheat Scoop ${ }^{\circledR}$.

- Trivalent nitrate salts, i.e., iron and aluminum, react at lower temperature with ligocellulosics than mono or divalent nitrate salts (i.e., $\mathrm{Na}, \mathrm{K}, \mathrm{Mg}, \mathrm{Ca}$, and $\mathrm{Pb}$ ).

○ Metals ( $\mathrm{Bi}, \mathrm{W}$, and $\mathrm{La}$ ) from the glovebox glove were not involved in the reaction.

- Other than one particle of Bi found on the lip of R16 C4, no Bi, W or La were found in the samples from R15 C5, R16 C4 or the CAM filters.

- At the time of the Real Time Radiography (RTR) of Drum 68660 performed at LANL, the glovebox glove was in the job control solid waste layer at the bottom of the drum physically separated from the neutralized liquid/Swheat Scoop ${ }^{\circledR}$ layer (see Appendix E, Addendum A); though unlikely, physical contact may have occurred to some degree during transport of the drum to WIPP.

- Reaction products are from metal nitrate oxidation of organics:

- Significant levels of nitrite and carbonate salts were found in the samples that were not present in the original waste stream. These compounds are products from the oxidation of carbohydrates (Swheat Scoop ${ }^{\circledR}$ ) by metal nitrate salts.

- Reaction inside the drum did not go to completion:

○ Materials ejected from the drum either did not experience temperatures over $200^{\circ} \mathrm{C}$, or their exposure to elevated temperatures was very limited in duration ( $<$ seconds) resulting in the observation of thermally sensitive materials in the collected samples.

○ Thermally sensitive materials (i.e., oxalate and nitrite salts) were found in ejected material that would not have survived a high temperature reaction.

○ Triethanolamine (TEA), a component of Kolorsafe ${ }^{\circledR}$ liquid acid neutralizer, was tentatively identified in a sample of the debris collected from R15 C5.

- Oxidation products were observed in the debris but nitration products were not detected:

○ Nonextractable oxidation products were detected but no lower molecular weight oxidation products were found.

○ Formation of nitrated (i.e., nitrate esters or nitro-containing) compounds cannot be ruled out but if they are present, they are in low concentration. 
- Formation of nitrated compounds is not necessary to produce an exothermic reaction, which could produce sufficient quantities of gas to cause the breach of drum 68660 .

$\circ$ The absence of triethanolammonium nitrate (TEAN) and TEAN decomposition products indicates the material potentially was consumed in the reaction.

- Eutectic mixture of nitrate salts could form:

- Although an exact ratio of the salts is not known, they are in a range in which a eutectic mixture of $\mathrm{Mg}, \mathrm{Na}, \mathrm{Ca}$, and $\mathrm{K}$ nitrate salts could form. While the melting temperature of the potential eutectic mixture is not precisely known, these results indicate that a liquefied eutectic mixture was possible in the drum environment, which could accelerate the oxidation reactions.

- Gases from truck fire did not cause the damage to the super sacks:

○ No evidence to support the presence of $\mathrm{Mg}(\mathrm{OH})_{2}, \mathrm{MgCO}_{3}$ or other metastable hydrous carbonate species that would be expected if the material in the super sacks was exposed to significant quantities of $\mathrm{CO}_{2}$ and/or $\mathrm{H}_{2} \mathrm{O}$ combustion products.

○ The low radioactivity on the exposed $\mathrm{MgO}$ on the adjacent drums indicates that the event was of short duration (seconds).

\subsection{SUMMARY OF ANALYTICAL PROCESS}

Samples collected from WIPP (as described in Appendix B: Sampling Integrated Summary Report) were sent to Pacific Northwest National Laboratory (PNNL), Savannah River National Laboratory (SRNL), and Lawrence Livermore National Laboratory (LLNL) for analysis. PNNL received the samples from the lip of R16 C4 and the top of standard waste box (SWB) R15 C5 taken on May 30, 2014 using the multisampler device. The bulk MgO samples from R14 C2, R14 C4, and R14 C6 and the MgO sample taken from the top of R16 C4 using the multi-sampler device were sent to SRNL. The second set of samples from the lip of R16 C4 and two samples from R15 C5 taken on August 15, 2014 were sent to SRNL for analysis, and a subsample of R15 C5 was sent to LLNL for LC-MS analysis. Samples of the debris and swipes from the parent drum were sent to SRNL for analysis.

The analytical approach for the samples was determined at the first meeting of the TAT on June 3-4, 2014 and followed standard practices for identification of unknown samples. [Magnuson, 2012] Analysis initially started with nondestructive analysis (optical and gamma analysis, XRD/XRF, SEM-EDS, Raman and/or FTIR) followed by destructive analysis (ICP-EOS, ICP-MS, IC, extraction/GC-MS, LC-MS, and TG-MS). Sets of instructions (called R\&D Directions at SRNL, Test Instructions at PNNL, Sample Preparation and Analysis Plan at LLNL) were prepared describing how the samples would be handled and analyzed. These instructions built off the existing analytical procedures and quality control documents already in place at PNNL, SRNL, and LLNL. These instructions were circulated to the WIPP TAT for review, comments were addressed and the final revised documents were approved by unanimous vote of the TAT. Work did not start until TAT approval was obtained. Each lab assigned its samples a unique sample (and tracking) number including all sample splits and sample transfers, which were tracked with a chain of custody (COC) form. The samples were photographed during all aspects of unpacking and transfer, and the samples were qualitatively surveyed for radioisotopes by nondestructive gamma analysis. An archive sample was maintained from all samples for future reference. The analytical details for each analysis and the raw data are presented in the Appendix (Analytical Results from PNNL, SRNL, and LLNL). A full discussion of the radiochemical analysis is presented in the Source Term Section and is not discussed here. Below is a high level summary of the analytical results followed by a discussion of how the analytical data supports the key judgments. 


\subsection{SUMMARY OF ANALYTICAL RESULTS}

The analytical efforts focused on the materials ejected onto the SWB R15 C5 to determine the reactions that occurred in drum 68660 that led to the breach. The samples from the lip of R16 C4 were much smaller and primarily contained MgO. Overall, the debris from R15 C5 was very heterogeneous and predominantly contained a mixture of inorganic salts. The primary metals identified were consistent with what was known to be in drum 68660 [see Thermal Modeling Section] (Mg, Na, Ca, Fe, Al, K, and Ni, note - Cr was observed in XRF but not in the ICP-OES,) while trace quantities (typically $<0.02 \mathrm{wt} \%$ ) of other metals (Ba, Mn, Ti, and $\mathrm{Zn}$ ) not noted in the original drum contents were observed. No $\mathrm{Bi}$, W, or $\mathrm{La}$ (from a glovebox glove) was detected by SEM-EDS, ICP-OES, ICP-MS, or micro-XRD analysis of the R15 C5 samples. The phosphorus observed in the R15 C5 samples most likely originated from the Swheat Scoop ${ }^{\circledR}$, which contains about 0.5 wt\% phosphorus. Lead was ubiquitous and in a R15 C5 sample, it was found in concentrations over 100 -fold greater than that predicted from the drum contents. This most likely arises from nitric acid leaching of the lead drum liner present within the parent drum during the decades of storage before processing. In addition to the anions expected based on the drum contents $\left(\mathrm{NO}_{3}{ }^{-}, \mathrm{F}^{-}\right.$, and oxalate), new anions were found in the debris including $\mathrm{NO}_{2}{ }^{-}, \mathrm{CO}_{3}{ }^{2-}$, and $\mathrm{Cl}^{-}$. The nitrite and carbonate are consistent with products expected from the reaction of carbohydrates with metal nitrate salts (see below). Significantly more metal cations were found than anions indicating that metal oxides are present in the debris. The debris from R15 C5 contained a small number of methylene chloride extractable organic compounds (and no additional compounds were observed after derivatization, reporting limit $2 \mathrm{ppm}$ ). A few low molecular weight organic acids (formic, acetic and oxalic) were observed in the water extract of R15 C5, but these acids were also found in the Swheat Scoop ${ }^{\circledR}$. FTIR and micro-fluorescence microscopy analyses of the debris and the methylene chloride extract were very complex and showed the presence of organic material that resembled Swheat Scoop ${ }^{\circledR}$ (i.e., carbohydrates) and inorganics materials (nitrates and carbonates). Oxidized materials were also identified in the FTIR spectra (by both bulk and micro-techniques) but no other degradation products of Swheat Scoop ${ }^{\circledR}$ or triethanolamine (TEA) could be identified. No nitrated organics or triethanolamine were detected by GC-MS or FTIR analysis. A sample of R15 C5 was sent to LLNL to analyze for polar, high molecular weight material by LC-MS using a high-resolution mass spectrometer capable of tandem mass spectrometry in positive electrospray mode. Unlike, GC-MS, no LC-MS libraries are available to assist in the identification of unknown compounds; however, by exploiting exact mass measurements, the presence of targeted compounds can be detected. Using this type of targeted analysis, triethanolamine was tentatively identified in the sample. TG-MS analysis of the debris from R15 C5 under argon showed unreacted material was present. The debris showed a total weight loss of $9.4 \%$ at $200{ }^{\circ} \mathrm{C}, 17 \%$ at $400{ }^{\circ} \mathrm{C}$ and a final weight loss of $35.1 \%$ at $1000^{\circ} \mathrm{C}$ indicating the material did not experience high temperatures. Gases evolved below $200{ }^{\circ} \mathrm{C}$ included $\mathrm{m} / \mathrm{z} 16\left(\mathrm{CH}_{4}\right), \mathrm{m} / \mathrm{z} 18\left(\mathrm{H}_{2} \mathrm{O}\right), \mathrm{m} / \mathrm{z} 30\left(\mathrm{NO}\right.$ and $\left.\mathrm{CH}_{2} \mathrm{O}\right)$ and $\mathrm{m} / \mathrm{z} 44$ $\left(\mathrm{CO}_{2}\right.$ and/or $\left.\mathrm{N}_{2} \mathrm{O}\right)$, and $\mathrm{m} / \mathrm{z} 46\left(\mathrm{NO}_{2}\right.$, and other materials), which is consistent with the decomposition of organics and metal nitrate salts.

The sample from the lip of R16 C4 was primarily MgO. The metals found in the sample were consistent with what was found in R15 C5 except the Pb was found in significantly lower concentrations. SEM analysis found pieces of steel in the sample (which could have originated from the drum). Although it was anticipated that organics would be present on the lip of 68660 since it was discolored, hard and crusty, only minor amounts of organic residues (such as carboxylic acids) were detected by micro-FTIR ATR, and no detectable amounts of organics were found in the methylene chloride extract. No triethanolamine or nitrated organics were detected by GC-MS or FTIR analysis. It is postulated that high molecular weight (methylene chloride insoluble) organic compounds derived from the Swheat Scoop ${ }^{\circledR}$ are responsible for the material on the lip of R16 C4 being hard and crusty.

The debris from parent drum S855793 was expected to be acidic based on the drum history and a water extract of the debris was found to be slightly acidic ( $\mathrm{pH}$ was 3.8, with a total acid content of $0.0157 \mathrm{~N}$ ). 
The anions in the water extract were consistent with the known contents of the waste stream (nitrate, fluoride, and sulfate) and the extractable anions from the Swheat Scoop ${ }^{\circledR}$ (formate, acetate, oxalate, chloride, sulfate, and phosphate). Since phosphorous was not in significant concentration in the waste stream $(<0.01 \mathrm{wt} \%)$, it is a good indicator of Swheat Scoop ${ }^{\circledR}$. The metals found in the debris were consistent with the drum contents ( $\mathrm{Mg}, \mathrm{Na}, \mathrm{Ca}, \mathrm{Al}, \mathrm{Fe}$, and $\mathrm{K}$ ) except for the high concentrations of lead (11.7 wt\%). The IAEA swipes only contained a trace amount of lead. No significant amount of organics was found from the methylene chloride extracts of the glass swipes by GC-MS (reporting limit $20 \mathrm{ppm}$ ). FTIR analysis of the extract detected inorganic material including carbonates and nitrates. Extraction of the debris with methylene chloride found long chain fatty acids (linoleic and palmitic acids), which are known to be present in Swheat Scoop ${ }^{\circledR}$. [Sramkova, 2009]

Many of the major materials found in the debris on R15 C5 were also found on the CAM and FAS filters. The materials on the CAM filters include anions (nitrate, nitrite, oxalate, acetate, formate, chloride, fluoride, and sulfate), metals (Mg, $\mathrm{Na}, \mathrm{Ca}, \mathrm{Fe}, \mathrm{Al}$, and $\mathrm{Pb}$ ), and organics (that have an FTIR spectra similar to Swheat Scoop ${ }^{\circledR}$ ). The materials on the FAS filters also include anions (nitrate, nitrite, formate, chloride, fluoride, and sulfate) and metals ( $\mathrm{Mg}, \mathrm{Na}, \mathrm{Fe}, \mathrm{Al}$, and $\mathrm{Pb}$ ). This indicates the material ejected from the drum formed aerosol particles that moved through the room and drift and were collected by the CAM and the FAS filters. This observation is supported by optical microscopy and SEM-EDS measurements of small salt particles on R15 C5 and R16 C4. Extremely small Pu and Pb particles (too small to be accurately measured by SEM but well below $100 \mathrm{~nm}$ in diameter) were found associated with larger, high-surface area "hairy" salt particles. The morphology and chemical makeup of these salts were significantly different from that naturally expected from the mine, and consistent with a rapid precipitation mechanism out of the entrained liquid known to be present within drum 68660 .

Magnesium oxide was collected from on top of adjacent drums (R14 C2, R14 C4, and R14 C6) and a reference sample was collected from an intact bag of $\mathrm{MgO}$ located on the floor at the waste face. The samples were white or beige colored and was composed of powder and pellets with an occasional dark particle. The MgO samples had low radioactivity, which indicated that the event was of short duration. If the radioactive material was slowly ejected from 68660 over a time frame of minutes, more radioactivity would be expected on the adjacent drum. XRD and FTIR analysis of the MgO from the drums indicated that no $\mathrm{Mg}(\mathrm{OH})_{2}, \mathrm{MgCO}_{3}$ or other metastable hydrous carbonate species was present that would be expected if the material in the super sacks was exposed to significant quantities of $\mathrm{CO}_{2}$ and/or $\mathrm{H}_{2} \mathrm{O}$ combustion products from the truck fire. Therefore, it is concluded that the truck fire event did not cause the damage observed in Panel 7 Room 7. 


\section{Parent Drum: Contents, Acidity and Metals}

In the Reaction Chemistry and Hypotheses discussion (Appendix F), it is proposed that a series of internal exothermic reactions produced sufficient gas pressure to breach drum 68660 . These reactions could have be initiated by a combination of chemical and/or radiolytically induced reactions between nitric acid, nitrate salts, metals, triethanolamine (TEA)/triethanolammonium nitrate (TEAN), and Swheat Scoop ${ }^{\circledR}$. It is important to define the contents of drum 68660 since these materials should be found in the debris on R15 C5 and the lip of R16 C4, and these materials are responsible for the exothermic reactions and the corresponding reaction products.

The contents of drum 68660 were estimated by Weisbrod starting from the Veazey salt analysis as described in the Thermal Modeling Section. The drum had a layer of job control waste (plastic/rubber) on the bottom, processed liquid layer consisting of Swheat Scoop ${ }^{\circledR} /$ nitric acid/Kolorsafe ${ }^{\circledR}$ liquid acid neutralizer (i.e., triethanolamine, water and Alizarin, an indicator dye), and a metal nitrate salt layer mixed with Swheat Scoop ${ }^{\circledR}$. The Swheat Scoop ${ }^{\circledR}$ was mixed with the liquids in a 3:1 volume ratio while Swheat $S c o o p{ }^{\circledR}$ was mixed with the nitrate salts in a 0.7:1 volume ratio. The molarity of the acid in the liquid layer and the interstitial liquid in the nitrate salts was 3.3M. [Clark, 2015] The estimated composition of the nitrate salt layer is shown in Table 1 . Note the initial $\mathrm{Pb}$ content is very small and no nitrites or carbonates were present.

Table 1. Composition of salts in 68660 (as described in the Cookoff Model Section).

\begin{tabular}{|l|l|}
\hline Component & $\mathrm{Wt} \%$ \\
\hline $\mathrm{Mg}\left(\mathrm{NO}_{3}\right)_{2} \cdot 6 \mathrm{H}_{2} \mathrm{O}$ & 62.3 \\
\hline $\mathrm{NaNO}$ & 13.7 \\
\hline $\mathrm{Ca}\left(\mathrm{NO}_{3}\right)_{2} \cdot 4 \mathrm{H}_{2} \mathrm{O}$ & 9.47 \\
\hline $\mathrm{Fe}\left(\mathrm{NO}_{3}\right)_{3} \cdot 9 \mathrm{H}_{2} \mathrm{O}$ & 6.45 \\
\hline $\mathrm{Al}\left(\mathrm{NO}_{3}\right)_{3} \cdot 9 \mathrm{H}_{2} \mathrm{O}$ & 2.38 \\
\hline $\mathrm{KNO}_{3}$ & 2.08 \\
\hline$(\mathrm{COOH})_{2}$ & 1.53 \\
\hline $\mathrm{HNO}$ & 1.53 \\
\hline $\mathrm{H}_{2} \mathrm{O}($ with trace elements $)$ & 0.20 \\
\hline $\mathrm{NaF}$ & 0.18 \\
\hline $\mathrm{Cr}\left(\mathrm{NO}_{3}\right)_{2} \cdot 9 \mathrm{H}_{2} \mathrm{O}$ & 0.13 \\
\hline $\mathrm{Ni}\left(\mathrm{NO}_{3}\right)_{2} \cdot 6 \mathrm{H}_{2} \mathrm{O}$ & 0.06 \\
\hline $\mathrm{Pb}\left(\mathrm{NO}_{3}\right)_{2}$ & 0.01 \\
\hline
\end{tabular}

2.1 Acidity of Parent Drum (S855793): The acidity of the waste stream is important in determining potential reaction chemistry. Swheat Scoop ${ }^{\circledR}$ is derived from the whole grain of wheat, which is primarily composed of starch (65-70\% dry weight) and proteins (14\%) with smaller amounts of lignin, lipids, other polymeric carbohydrates including cellulose, and minerals. Dilute nitric acid is known to hydrolyze and oxidize hemicellulose, starch, and amorphous regions of cellulose to monosaccharides, polysaccharides, carboxylic acids (including acetic and oxalate acid [Sullivan, 1983]) and aldehydes (like hydroxymethyl furfural). [Rodriguez-Choong, 2004; Bensah, 2013; Fontana, 2008] Concentrated nitric acid or a combination of nitric acid with a dehydrating reagent like sulfuric acid leads to nitration reactions to form nitrate esters and nitro compounds [Ola, 1989]. Heating concentrated (69\%) nitric acid to $180^{\circ} \mathrm{C}$ can result in complete mineralization of the primary components of biomass (carbohydrates, carboxylic acids). [Würfels, 1989] In test reactions run at LANL [Clark, 2015], it was also shown that nitric acid lowers the temperature where decomposition and/or exothermic reactions can occur for both 
Swheat Scoop ${ }^{\circledR}$ and TEA. Thus, the acidity of the waste stream can contribute to the degradation of the Swheat Scoop ${ }^{\circledR}$.

During processing of the parent drum (S855793), it was documented that approximately 2 gallons of liquid was collected with a $\mathrm{pH}$ of 0 , measured by $\mathrm{pH}$ paper, and neutralized with Kolorsafe ${ }^{\circledR}$. Based on process knowledge, the nitrate salts from the ion exchange process were washed with 3.3M nitric acid, while nitrate salts from the oxalate filtrates were not washed with bulk acid because it would accelerate decomposition of the oxalic acid present in the salts. [Clark, 2015] Typically, after emptying a drum and remediating its contents, a little adsorbent, Swheat Scoop ${ }^{\circledR}$, was added into the empty drum to adsorb any residual liquids. The parent drum (S855793) of 68660 was sampled as described in the Appendix B (Sampling Integrated Summary Report) to learn more about the contents of the drum. The dry solid debris was extracted with water and the total acid content was determined to be $0.0157 \mathrm{~N}$ by titration. The total acid content for a water extract of Swheat $S \operatorname{coop}{ }^{\circledR}$ was 0.0050 N. The free acid available in the solid, which represents the free $\mathrm{H}^{+}$concentration (in $20 \mathrm{~mL}$ of solution) relative to the mass of the sample (0.6901g), is $0.455 \mathrm{~mol} / \mathrm{Kg}$, which is similar to quantities measured by LANL for samples taken from other empty parent drums with acidic liquid [Martinez, 2014]. Although it is not possible to back calculate the acidity of the original drum, this does confirm the materials in the parent drum were acidic.

The water extract from the debris from the parent drum was also analyzed by ion chromatography. As expected, the dominant anions were nitrate $(12.6 \mathrm{wt} \%)$ and oxalate $(0.264 \mathrm{wt} \%)$ with smaller amounts of chloride (899 $\mu \mathrm{g} / \mathrm{g})$, sulfate $(290 \mu \mathrm{g} / \mathrm{g})$, and formate $(638 \mu \mathrm{g} / \mathrm{g})$. Acetate and fluoride were also observed but they could not be quantitated because they co-eluted. Swheat Scoop ${ }^{\circledR}$ was also found to contain water extractable ions including small amounts ( $<0.05 \mathrm{wt} \%)$ of chloride $(480 \mu \mathrm{g} / \mathrm{g})$, formate $(332 \mu \mathrm{g} / \mathrm{g})$, nitrate $(240 \mu \mathrm{g} / \mathrm{g})$, oxalate ( $240 \mu \mathrm{g} / \mathrm{g})$, and sulfate (435 $\mu \mathrm{g} / \mathrm{g})$. Phosphate was found in higher concentrations $(0.50 \mathrm{wt} \%)$, and since it is not in found in significant concentrations in the waste stream $\left(<0.01 \mathrm{wt} \%\right.$ ), phosphate can be used as a signature of Swheat Scoop ${ }^{\circledR}$ in the debris. Overall, the anions detected in the parent drum were consistent with the content of 68660 and Swheat Scoop ${ }^{\circledR}$.

2.2 Metals in Parent Drum (S855793): Metals could potentially act as catalyst to accelerate the decomposition of the organic materials as discussed in the Reaction Chemistry and Hypotheses appendix (Appendix F). Thus, the metals in the parent drum were qualitatively analyzed by SEM-EDS, and quantitated by ICP-OES and ICP-MS using a mixed acid $\left(\mathrm{HNO}_{3} / \mathrm{HCl} / \mathrm{HF}\right.$ in a 2:1:1 volume ratio) digestion and peroxide $\left(\mathrm{Na}_{2} \mathrm{O}_{2}\right)$ fusion (which is more aggressive and can provide a higher recovery of the metals). Since Swheat Scoop ${ }^{\circledR}$ was added to the empty parent drum to adsorb any residual liquids, the metals found in the debris are representative of the metals in the liquid, except for the pieces of metal from the drum. SEM-EDS analysis of the chunks of debris from the parent drum were found to contain predominately $\mathrm{Pb}$ with smaller amounts of $\mathrm{Na}, \mathrm{Mg}, \mathrm{Al}, \mathrm{K}$, Ca and $\mathrm{K}$ (see Figure 1). Quantitative analyses

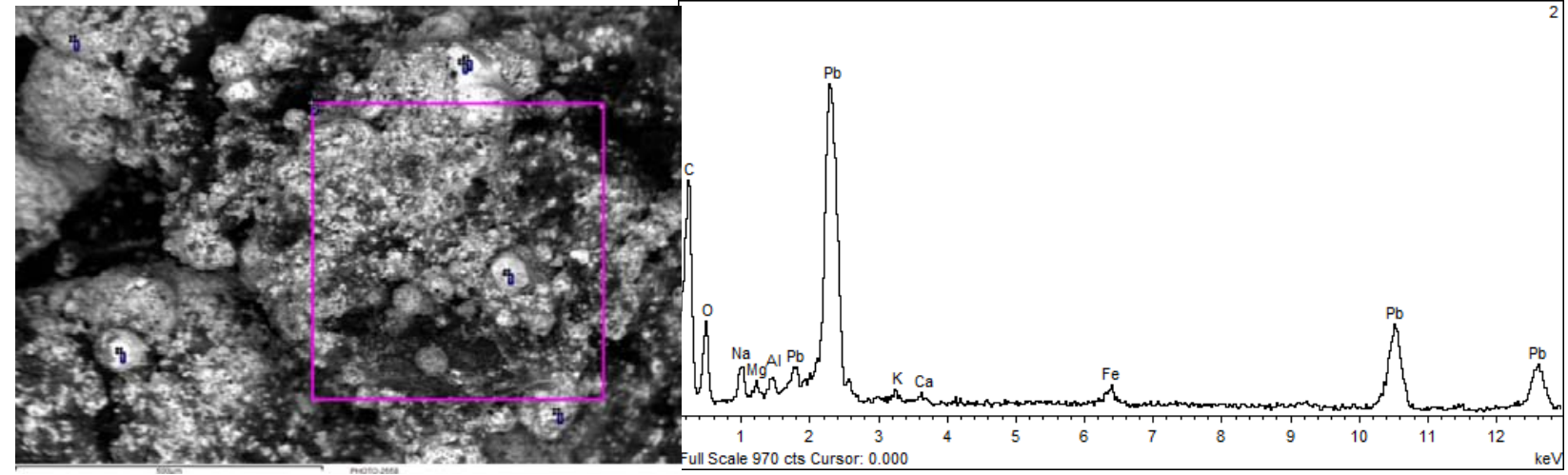

Figure 1. SEM (A) and EDS (B) analysis of the debris from the parent drum. 
of one sample found $11.7 \mathrm{wt} \% \mathrm{~Pb}$ and $2.8 \mathrm{wt} \% \mathrm{Na}$. Other metals detected which were expected based on drum contents included Al (9050 ppm), Fe (7300 ppm), Mg (5010 ppm), K (1270 ppm), Ca (573 ppm), $\mathrm{Cr}$ (843 ppm), and Ni (343 ppm). Additional metals detected include U (3540 ppm), Ba (1610 ppm), Zn (643 ppm), Cu (290 ppm), Mn (23 ppm), and Sr (19 ppm). Some of these metals were also found in the Swheat Scoop ${ }^{\circledR}$ including $\mathrm{Na}, \mathrm{Al}, \mathrm{K}, \mathrm{P}, \mathrm{Mg}, \mathrm{Ca}$, and $\mathrm{Si}$. There are no significant amounts of metal in the debris that are unexpected based on the contents of 68660 except for the high lead concentration.

Martinez and Chamberlin reported similar results in the analysis of other parent drums in which high $\mathrm{Pb}$ (19-42 wt\%) and sodium (1.7-3.7 wt\%) concentrations were observed and similar metals were found.

[Martinez, 2014]

Conclusions from Analysis of the Parent Drum: The metals found in the debris and the acidic environment found in the parent drum are known to accelerate the decompostion of the organic materials found in Swheat Scoop ${ }^{\circledR}$. The metals were consistent with the drum history except for the high levels of lead, which most likely arise from nitric acid leaching of the lead drum liner present within the parent drum during the decades of storage before processing. Since phosphorus is not found in high concentration in the waste stream, phosphorus can be used to identify the presence of Swheat Scoop ${ }^{\circledR}$ in the debris samples.

\section{Exothermic Oxidation of Organics by Nitrate Salts}

3.1 Predicted Reaction Products: The potential reactions that could lead to a series of internal exothermic reactions and produce sufficient gas pressure to breach drum 68660 are discussed in Appendix F, Reaction Chemistry and Hypotheses. In all cases, these reactions would produce specific products indicative of the reaction history. Thus, reaction products could arise from: (a) the hydrolysis, oxidation, and nitration of Swheat Scoop ${ }^{\circledR}$ (or more specifically carbohydrates) by nitric acid and/or metals; (b) the reaction of the metal nitrate salts and Swheat Scoop ${ }^{\circledR}$ (as discussed below); (c) the decomposition of the TEAN/Swheat Scoop ${ }^{\circledR}$ layer; (d) ionizing radiation from the radioactive decay of the transuranic elements in the waste; or/and (e) biotic reactions. Thus, the debris on the standard waste box R15 C5 and the material on the lip of breached drum were analyzed for potential reaction products from the materials in drum 68660.

Nitrate salts are known to react with organics to produce inorganics products and volatile gases. For example, PNNL investigated the use of carbohydrates (sugars) to denitrate low-activity waste, which was acidic and high in nitrates and alkali metals [Smith, 1999]. The goal of PNNL studies was to remove the nitrates at modest temperatures $\left(250-400{ }^{\circ} \mathrm{C}\right)$ and make $\mathrm{N}_{2}$ rather than nitrogen oxides $\left(\mathrm{NO}_{2}, \mathrm{NO}, \mathrm{N}_{2} \mathrm{O}\right)$. The denitration reaction proceeded as follows:

$$
1.25 \mathrm{C}_{\mathrm{n}} \mathrm{H}_{2 \mathrm{n}} \mathrm{O}_{\mathrm{n}}+\mathrm{nNaNO}_{3}=>(0.5 n) \mathrm{N}_{2}+(0.75 n) \mathrm{CO}_{2}+(1.25 n) \mathrm{H}_{2} \mathrm{O}+(0.5 n) \mathrm{Na}_{2} \mathrm{CO}_{3}
$$

Depending on the ratio of organic (fuel) to nitrate salt (oxidizer), a range of products including $\mathrm{CO}, \mathrm{N}_{2} \mathrm{O}$ or NO could be formed. For example, for the reaction of cellulose with sodium nitrate at a 1:1 C:N ratio, the products are:

$$
\mathrm{C}_{6} \mathrm{H}_{10} \mathrm{O}_{5}+6 \mathrm{NaNO}_{3}=>2 \mathrm{~N}_{2}+3 \mathrm{CO}_{2}+5 \mathrm{H}_{2} \mathrm{O}+3 \mathrm{Na}_{2} \mathrm{CO}_{3}+\mathrm{N}_{2} \mathrm{O}+\mathrm{O}_{2}
$$

Carboxylic acids, from the acid hydrolysis of Swheat Scoop ${ }^{\circledR}$, could react with nitrate salts to form similar products. Kozlowski and Bartholomew [1968] studied the decomposition of sodium formate and sodium acetate in molten sodium nitrate and sodium nitrite at $320^{\circ} \mathrm{C}$. The products from the reaction were similar to those found in the reaction of carbohydrates except sodium nitrite was found as a reaction intermediate (as shown below). 


$$
\begin{gathered}
\mathrm{NaC}_{2} \mathrm{H}_{3} \mathrm{O}_{2}+4 \mathrm{NaNO}_{3}=>0.5 \mathrm{Na}_{2} \mathrm{CO}_{3}+1.5 \mathrm{CO}_{2}+1.5 \mathrm{H}_{2} \mathrm{O}+4 \mathrm{NaNO}_{2} \\
\mathrm{NaC}_{2} \mathrm{H}_{3} \mathrm{O}_{2}+3 \mathrm{NaNO}_{2}=>2 \mathrm{Na}_{2} \mathrm{CO}_{3}+1.5 \mathrm{H}_{2} \mathrm{O}+0.5 \mathrm{~N}_{2} \mathrm{O}+\mathrm{N}_{2}
\end{gathered}
$$

These reactions were very vigorous and produced large amounts of gas. In general, it was observed that the lower the concentration of organic, the higher the allowable operating temperatures. It was also noted that sodium hydroxide could be formed in the reaction but it would rapidly react with the $\mathrm{CO}_{2}$ in the melt producing $\mathrm{Na}_{2} \mathrm{CO}_{3}$ and $\mathrm{H}_{2} \mathrm{O}$.

Magnesium nitrate has been shown to reduce the decomposition temperature of amylose from $280{ }^{\circ} \mathrm{C}$ to ca. $150{ }^{\circ} \mathrm{C}$. [Desai, 1972] It was proposed that $\mathrm{NO}_{2}$, generated at low temperature, was responsible for the low temperature oxidation of the amylose. Wu and Zavarin [1986] investigated the reaction of 20 different inorganic nitrate salts with lignocellulosic materials (including wood flour, cellulose, lignin, and xylan) and proposed that the exotherms between $100-200{ }^{\circ} \mathrm{C}$ most likely arose from the $\mathrm{NO}_{2}$ oxidation of lignocellulosics (to form NO and carboxylate salts). They also found that the first exothermic peak in the DSC of a mixture of nitrate-lignocellulose materials decreased as the acidity of the nitrate salt increased (as shown in Table 2). Kochkar et al. [2001] also reported the oxidation of starch by $\mathrm{NO}_{2}$ at $70{ }^{\circ} \mathrm{C}$ produced carboxylic acids. Solid state ${ }^{13} \mathrm{C}$ NMR showed that the primary $-\mathrm{CH}_{2} \mathrm{OH}$ group in starch was oxidized while the secondary carbons were less affected.

\begin{tabular}{|c|c|c|c|c|}
\hline Nitrate Salt & $\begin{array}{c}\mathrm{pH} \text { of } 1 \mathrm{~N} \\
\text { solution }\end{array}$ & $\begin{array}{l}\text { Wood Flour } \\
\left({ }^{\circ} \mathrm{C}\right)^{\mathrm{a}}\end{array}$ & $\begin{array}{l}\text { Xylan } \\
\left({ }^{\circ} \mathrm{C}\right)^{\mathrm{a}}\end{array}$ & $\begin{array}{l}\text { Microcrystalline } \\
\text { Cellulose }\left({ }^{\circ} \mathrm{C}\right)^{\mathrm{a}}\end{array}$ \\
\hline $\mathrm{Fe}\left(\mathrm{NO}_{3}\right)_{3}$ & 1.11 & 96 & 123 & 154 \\
\hline $\mathrm{Al}\left(\mathrm{NO}_{3}\right)_{3}$ & 2.24 & 126 & 147 & 178 \\
\hline $\mathrm{Pb}\left(\mathrm{NO}_{3}\right)_{2}$ & 3.45 & 202 & 207 & 185 \\
\hline $\mathrm{Mg}\left(\mathrm{NO}_{3}\right)_{2}$ & 4.61 & 200 & 190 & 215 \\
\hline $\mathrm{Ca}\left(\mathrm{NO}_{3}\right)_{2}$ & 5.13 & 217 & 232 & 247 \\
\hline $\mathrm{NaNO}_{3}$ & 6.52 & 260 & NM & 276 \\
\hline
\end{tabular}

Table 2. DSC data for reaction between lignocellulosics and various nitrate salts. [Wu, 1986]

${ }^{a}$ Peak temperature for the first oxidation exotherm in the DSC (800psi, $\mathrm{N}_{2}$ ). NM- not measured

For the materials in drum 68660, the potential decomposition products were determined by the thermoequilibrium code CTH-TIGER (Thermal Modeling Appendix). This model includes the Swheat Scoop ${ }^{\circledR} /$ processed liquid layer (TEAN) and the Swheat Scoop ${ }^{\circledR} /$ nitrate salt layer (see Table 1) but does not include the plastic/rubber job waste on the bottom of the drum. The model predicts an exothermic reaction $\left(-2.17 \times 10^{6} \mathrm{~J} / \mathrm{kg}\right)$ producing the equilibrium composition of products at $227^{\circ} \mathrm{C}$ at 1 atmosphere, as shown below.

$$
\begin{array}{r}
\mathrm{C}_{1.15} \mathrm{H}_{4.72} \mathrm{O}_{3.07} \mathrm{~N}_{0.40} \mathrm{Mg}_{0.094} \mathrm{Na}_{0.057} \mathrm{Ca}_{0.015} \mathrm{Fe}_{0.006}=>1.6 \mathrm{H}_{2} \mathrm{O}+0.53 \mathrm{CO}_{2}+0.20 \mathrm{~N}_{2}+0.37 \mathrm{CH}_{4}+0.02 \mathrm{H}_{2} \\
+0.002 \mathrm{Fe}_{2} \mathrm{O}_{3}+0.11 \mathrm{C}(\mathrm{s})+0.079 \mathrm{MgCO}_{3}+0.028 \mathrm{Na}_{2} \mathrm{CO}_{3}+0.015 \mathrm{CaMgC}_{2} \mathrm{O}_{6}
\end{array}
$$

In addition to the nitrate salts reacting with organics, the salts can decompose depending on the reaction temperature. [Stern, 1972]. In general, divalent nitrate salts (Mg and Ca) decompose at a lower temperature than the monovalent nitrate salts ( $\mathrm{Na}$ and $\mathrm{K}$ ) to form the metal oxide as shown below. These decomposition products can then oxidize and/or nitrate organics materials (as previously discussed).

$$
\begin{gathered}
\mathrm{Mg}\left(\mathrm{NO}_{3}\right)_{2}=>\mathrm{MgO}+2 \mathrm{NO}_{2}+0.5 \mathrm{O}_{2} \\
2 \mathrm{NaNO}_{3}=>\mathrm{Na}_{2} \mathrm{O}+2 \mathrm{NO}_{2}+0.5 \mathrm{O}_{2}
\end{gathered}
$$


Most ionic salts melt to form liquids stable to various degrees before decomposition. $\mathrm{Mg}\left(\mathrm{NO}_{3}\right)_{2}$ and $\mathrm{Ca}\left(\mathrm{NO}_{3}\right)_{2}$ are stable up to about $325^{\circ} \mathrm{C}$ and $425^{\circ} \mathrm{C}$, respectively while $\mathrm{NaNO}_{3}$ and $\mathrm{KNO}_{3}$ decomposes around $600{ }^{\circ} \mathrm{C}$ and $650^{\circ} \mathrm{C}$, respectively. However, the decomposition depends on the reaction environment. For example, it has been reported that $\mathrm{Mg}\left(\mathrm{NO}_{3}\right)_{2}$ decomposed (to $\left.\mathrm{Mg}\left(\mathrm{NO}_{2}\right)_{2}\right)$ at $125{ }^{\circ} \mathrm{C}$ in a NO atmosphere. [Stern, 1972]

In general, nitrite salts are less stable than nitrate salts. For example, $\mathrm{NaNO}_{2}$ has been reported to be unstable above $330{ }^{\circ} \mathrm{C}$ and $\mathrm{KNO}_{2}$ is unstable above $410{ }^{\circ} \mathrm{C}$. [Stern, 1972] The decomposition of nitrites and nitrates depend on the environment as shown below.

$$
\begin{aligned}
& 2 \mathrm{NaNO}_{2}=>\mathrm{Na}_{2} \mathrm{O}+\mathrm{NO}_{2}+\mathrm{NO} \\
& 2 \mathrm{NO}+\mathrm{NaNO}_{2}=>\mathrm{NaNO}_{3}+\mathrm{N}_{2} \\
& \mathrm{NaNO}_{2}+\mathrm{NO}_{2}=>\mathrm{NaNO}_{3}+\mathrm{NO}
\end{aligned}
$$

The trivalent metal nitrates, i.e., iron and aluminum, have a different decomposition pathway than that of the mono- and di-valent nitrate salts and produce $\mathrm{HNO}_{3}$, rather than $\mathrm{NO}_{2}$, as the major product at temperatures around $150^{\circ} \mathrm{C}$. [Wieczorerk-Ciurowa, 1999; Keely, 1963; Melnikov, 2013]

$$
\begin{gathered}
2 \mathrm{Al}\left(\mathrm{NO}_{3}\right)_{3} \cdot 8 \mathrm{H}_{2} \mathrm{O}=>\mathrm{Al}_{2} \mathrm{O}_{3}+4 \mathrm{HNO}_{3}+\mathrm{N}_{2} \mathrm{O}_{3}+\mathrm{O}_{2}+14 \mathrm{H}_{2} \mathrm{O} \\
2 \mathrm{Fe}\left(\mathrm{NO}_{3}\right)_{3} \cdot 9 \mathrm{H}_{2} \mathrm{O}=>\mathrm{Fe}_{2} \mathrm{O}_{3}+6 \mathrm{HNO}_{3}+15 \mathrm{H}_{2} \mathrm{O}
\end{gathered}
$$

Triethanolammonium nitrate (TEAN) is an organic nitrate salt that melts at $80{ }^{\circ} \mathrm{C}$ and a has a broad exotherm (in the DSC) with an onset temperature of $251^{\circ} \mathrm{C}$. [Bracuti, 1992] Pyrolysis of the liquid propellant LGP1845, which is composed of hydroxylammonium nitrate (63.2 wt\%), TEAN (20 wt\%) and water (16.8 wt\%), produced NO, $\mathrm{N}_{2} \mathrm{O}, \mathrm{N}_{2}, \mathrm{CO}_{2}, \mathrm{CO}, \mathrm{H}_{2} \mathrm{O}, \mathrm{HCN}$, and $\mathrm{C}_{2} \mathrm{H}_{4}$ at temperatures between 130$540{ }^{\circ} \mathrm{C}$. [Chang, 2001] Pyrolysis of TEAN (under $200 \mathrm{psi}$ Ar and a heating rate of $175^{\circ} \mathrm{C} \mathrm{s}^{-1}$ ) exhibited an exotherm at $250-325^{\circ} \mathrm{C}$ and the formation of $\mathrm{CO}_{2}, \mathrm{~N}_{2} \mathrm{O}, \mathrm{CO}, \mathrm{NO}, \mathrm{NH}_{3}$, and $\mathrm{HCN}$. [Cronin, 1988] Laser heating of TEAN under argon produced water as the dominate product, and a series of other products similar to previous reported study including $\mathrm{HCN}, \mathrm{NH}_{3}, \mathrm{NO}, \mathrm{H}_{2} \mathrm{CO}, \mathrm{CH}_{3} \mathrm{CHO}, \mathrm{CO}, \mathrm{H}_{2}, \mathrm{CO}_{2}$, $\mathrm{CH}_{4}, \mathrm{C}_{2} \mathrm{H}_{4}, \mathrm{CH}_{3} \mathrm{CN}, \mathrm{N}_{2} \mathrm{O}$, and $\mathrm{NO}_{2}$. [Lee, 1999] Overall, the decomposition products from TEAN are gaseous.

Triethanolamine (TEA) can form complexes with metal ions through the oxygen and/or nitrogen atoms. [Naiini, 1997; Masoud, 2002] Thus, the free hydroxyl groups of TEAN could complex metals. Thermal analysis (DTA/TG/DTG) of TEA metal complexes typically showed an endotherm (melting) follow by an exotherm accompanied by weight loss. For example, $\mathrm{Fe}(\mathrm{TEA})_{2} \mathrm{Cl}_{3}$ shows an endotherm corresponding to melting $\left(165^{\circ} \mathrm{C}\right.$ ) immediately followed by an exotherm (ranging from $187-273{ }^{\circ} \mathrm{C}$ and $273-302{ }^{\circ} \mathrm{C}$ but centered at $251^{\circ} \mathrm{C}$ and $287^{\circ} \mathrm{C}$, respectively). [Içbudak, 1996] Similar behavior was also noted for TEA complexes with metal saccharinates in which an exotherm was measured at $150-300{ }^{\circ} \mathrm{C}$ with mass loss before or after melting. [Yilmaz, 2002] Unfortunately, there are few studies on the solid products formed from the thermal degradation of TEA metal complexes at temperatures between $150-500{ }^{\circ} \mathrm{C}$, which would help guide the search for products in the debris on R15 C5.

Conclusion: From the reactions described above, the primary products expected from the oxidation of Swheat Scoop ${ }^{\circledR}$ by metal nitrate salts are volatile gases $\left(\mathrm{N}_{2} \mathrm{O}, \mathrm{N}_{2}, \mathrm{CO}_{2}, \mathrm{NO}\right)$, combustible gases $\left(\mathrm{CH}_{4}, \mathrm{H}_{2}\right.$, and $\mathrm{CO})$, inorganic salts $\left(\mathrm{Na}_{2} \mathrm{CO}_{3}, \mathrm{NaNO}_{2}, \mathrm{MgCO}_{3}\right.$ and $\left.\mathrm{CaMgC}_{2} \mathrm{O}_{6}\right)$, carbon, water and nitric acid. The trivalent nitrate salts (Fe and $\mathrm{Al}$ ) appears to be more reactive than the divalent $(\mathrm{Mg}, \mathrm{Ca}$, and $\mathrm{Pb}$ ) and monovalent nitrate salts ( $\mathrm{Na}$ and $\mathrm{K}$ ). Depending on the reaction temperature, the nitrate salts could decompose and release reactive species, i.e., $\mathrm{O}_{2}$ and $\mathrm{NO}_{2}$, that would accelerate the decomposition of Swheat Scoop ${ }^{\circledR}$. 
3.2 Optical and Electron Microscopy of WIPP Samples: The samples from R15 C5 were

heterogeneous containing a variety of large $(\mathrm{cm}-\mathrm{mm})$ and small $(\mu \mathrm{m}-\mathrm{nm})$ sized particles, which contained a complex mixture of organic and inorganic materials. Although visual inspection of the particles for the two R15 C5 samples did not reveal any Swheat Scoop ${ }^{\circledR}$ present, micro-fluorescence, an empirical technique, identified particles with a spectrum similar to that of unreacted Sweat Scoop ${ }^{\circledR}$ (see Figure 2). It is possible that the Swheat Scoop ${ }^{\circledR}$ could be coated in salt (Figure 3) or degraded (Figure 4), obscuring its identity. Many small particles ranging in size from 1-10 $\mu \mathrm{m}$ were observed by SEM-EDS (see Figures 5 and 6). These particles predominately contained $\mathrm{Mg}, \mathrm{O}$ and $\mathrm{Na}$ with small amounts of $\mathrm{K}, \mathrm{Ca}$, and $\mathrm{Cl}$. Magnesium and sodium rich areas were found throughout the samples. In backscatter imaging, $\mathrm{Pb}$ was observed in almost all the samples with smaller amounts of Al, P, Fe and occasional Si. Small pieces of steel, most likely from the drum were found on the lip of R16 C4 (see Figure 7). Micro-XRF analysis was also performed on small samples taken from R15 C5 and R16 C4. Those analyses were not quantifiable, due to limitations caused by the presence of a slip cover required to manage radioactive contamination risks, but $\mathrm{K}, \mathrm{Ca}, \mathrm{Cr}, \mathrm{Fe}, \mathrm{Zn}, \mathrm{Cu}, \mathrm{Pb}$, and Mo were commonly identified in most scans. The elements $\mathrm{La}, \mathrm{W}$, and $\mathrm{Bi}$, from a glovebox glove, were not observed in scans of over 100 randomly chosen particles. ICP-OES quantitated the $\mathrm{Pb}$ as 0.57 and $0.77 \mathrm{wt} \%$ in the two R15 C5 samples, which is about 100 -fold more concentrated than the $\mathrm{Pb}$ in the waste stream (see Table 1). This high $\mathrm{Pb}$ concentration must arise from nitric acid leaching of the $\mathrm{Pb}$ liner in the parent drum over the past 28 years of storage before processing. Overall, the elements $\mathrm{Mg}, \mathrm{Na}, \mathrm{K}, \mathrm{Ca}, \mathrm{Al}$, and $\mathrm{Fe}$ are consistent with what is known to be in Drum 68660 (Table 1) while $\mathrm{Cl}$ and Si could arise from the WIPP salt or the MgO. The phosphorous most likely arises from the Swheat Scoop ${ }^{\circledR}$ because phosphorous is not present in significant concentration $(<0.01 \mathrm{wt} \%)$ in the waste stream but it is found in the native Swheat Scoop ${ }^{\circledR}$ (0.5 wt\%).
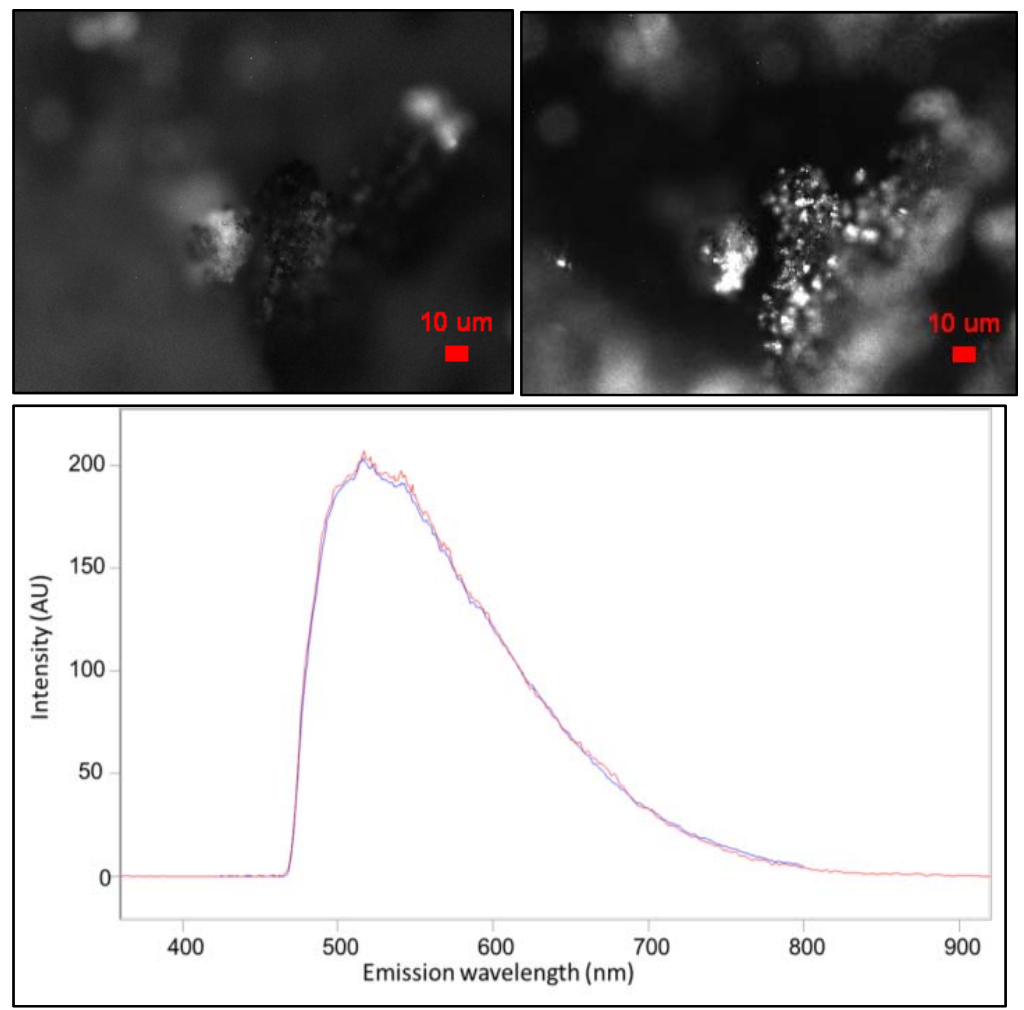

Figure 2. (a) Particle under white light and a 10x objective. (b) Particle illuminated by an excitation band of 375-425 $\mathrm{nm}$ observing the emission of $475 \mathrm{~nm}$ and longer. (c) The emission spectra of particle (blue) overlaid with the tvpical kittv litter (red). 


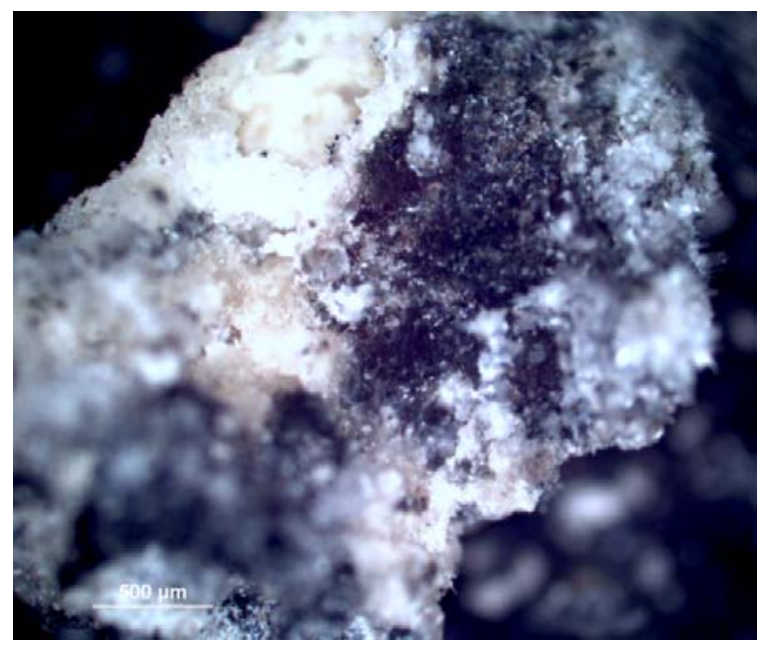

Figure 3. Optical microscopy of R15 C5 particles.

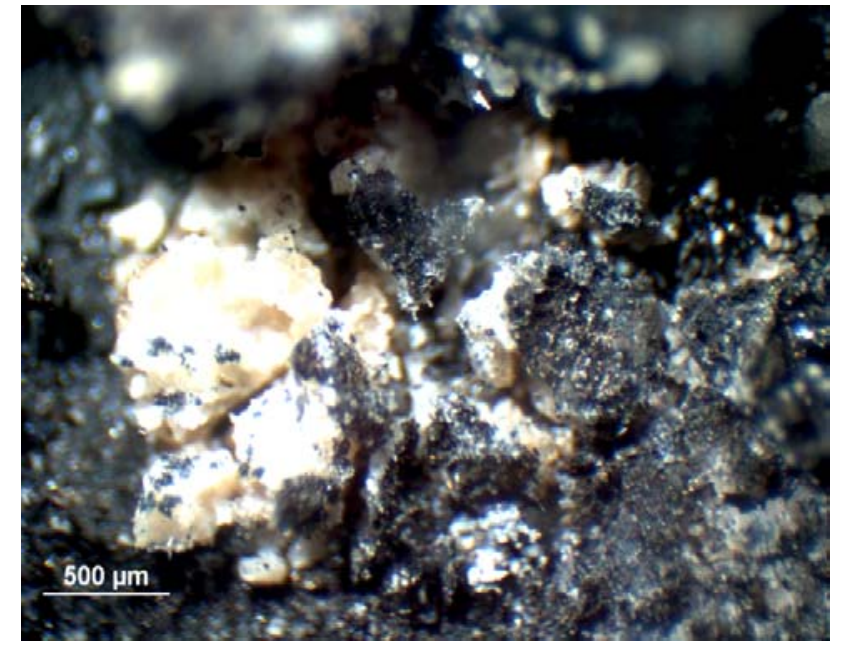

Figure 4. Optical microscopy of R15 C5 particles.

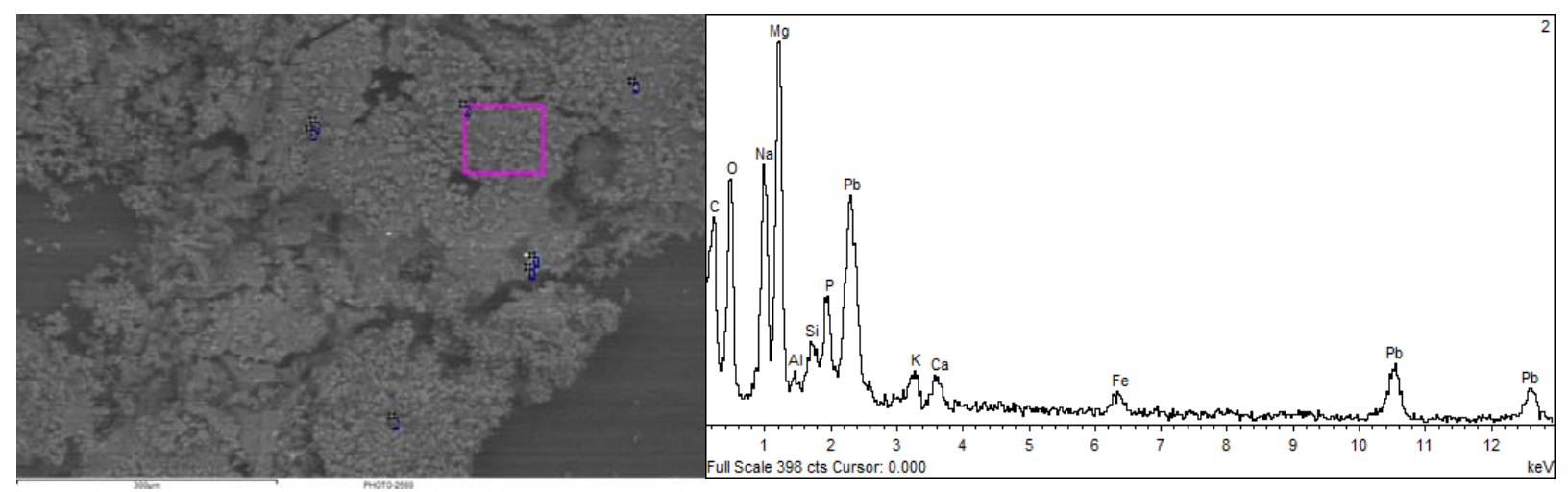

Figure 5. (a) SEM image of particles collected from R15 C5 and (b) Representative EDS of sample.

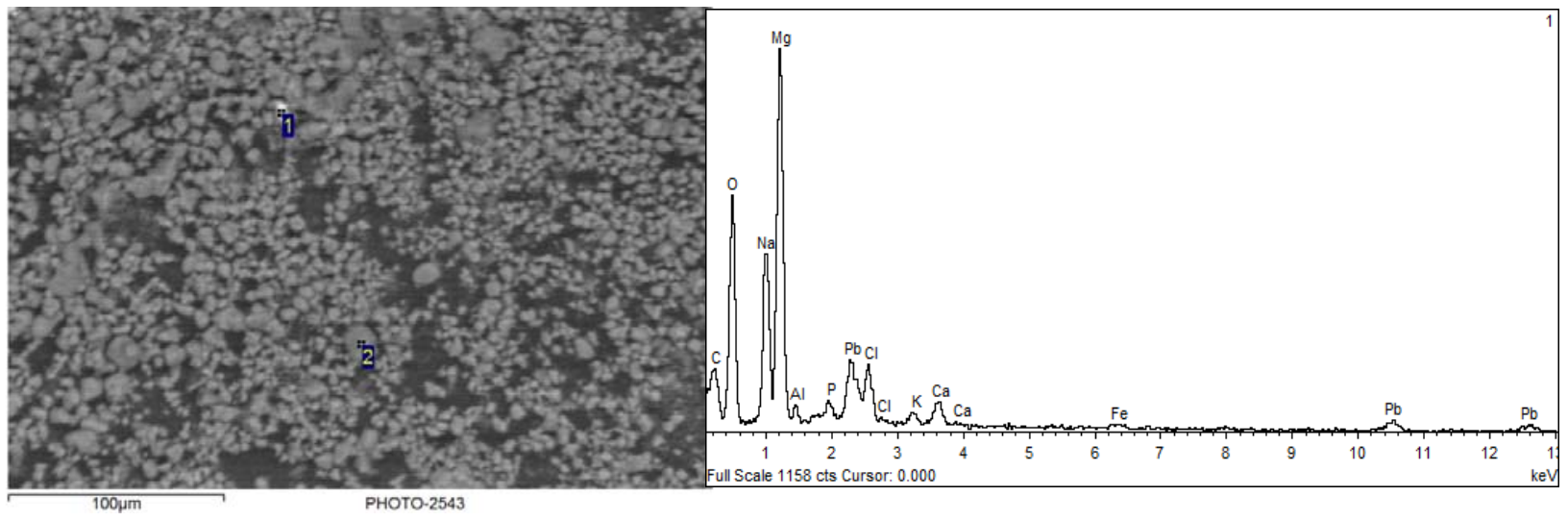

Figure 6. (a) SEM of small particles from R15 C5 and (b) EDS of particles. 


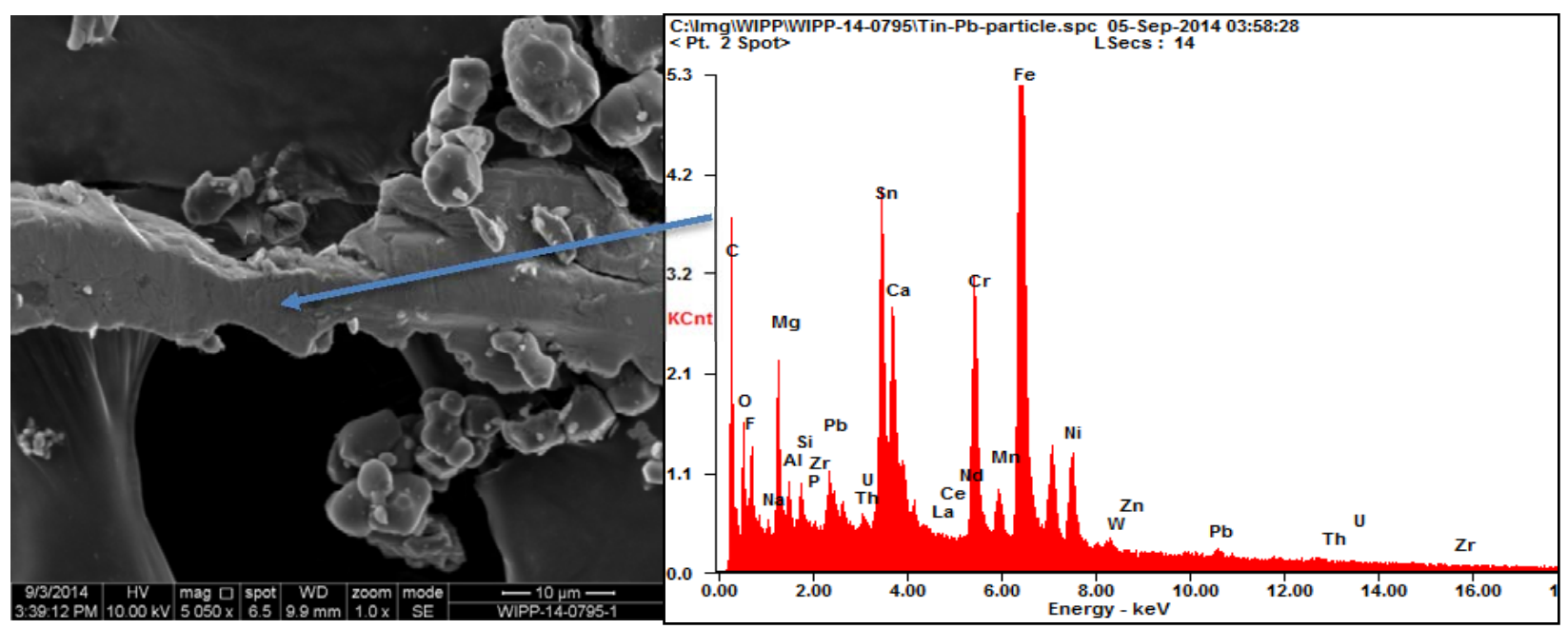

Figure 7. Elongated piece of steel from the sample collected from the lip of R16 C4.

Optical microscopy and SEM analysis of the R15 C5 samples showed salt particles that could have originated from the mine or the drum (see Figure 8). The Carlsbad salt is a well-described material. It is a Precambrian mineral, 250 million years old and tends to contain numerous inclusions. Figure 8a shows a salt particle with a morphology and characteristics (inclusions, etc.) indicative of the Precambrian salt from the mine. This spiny or whisker-like material shown in Figure 8b was found infrequently, but was observed in all the samples. A similar type of phase was observed during the SEM examination of the R16 C4 lip sample, but it was not identified during the optical microscopy examination of the same sample.
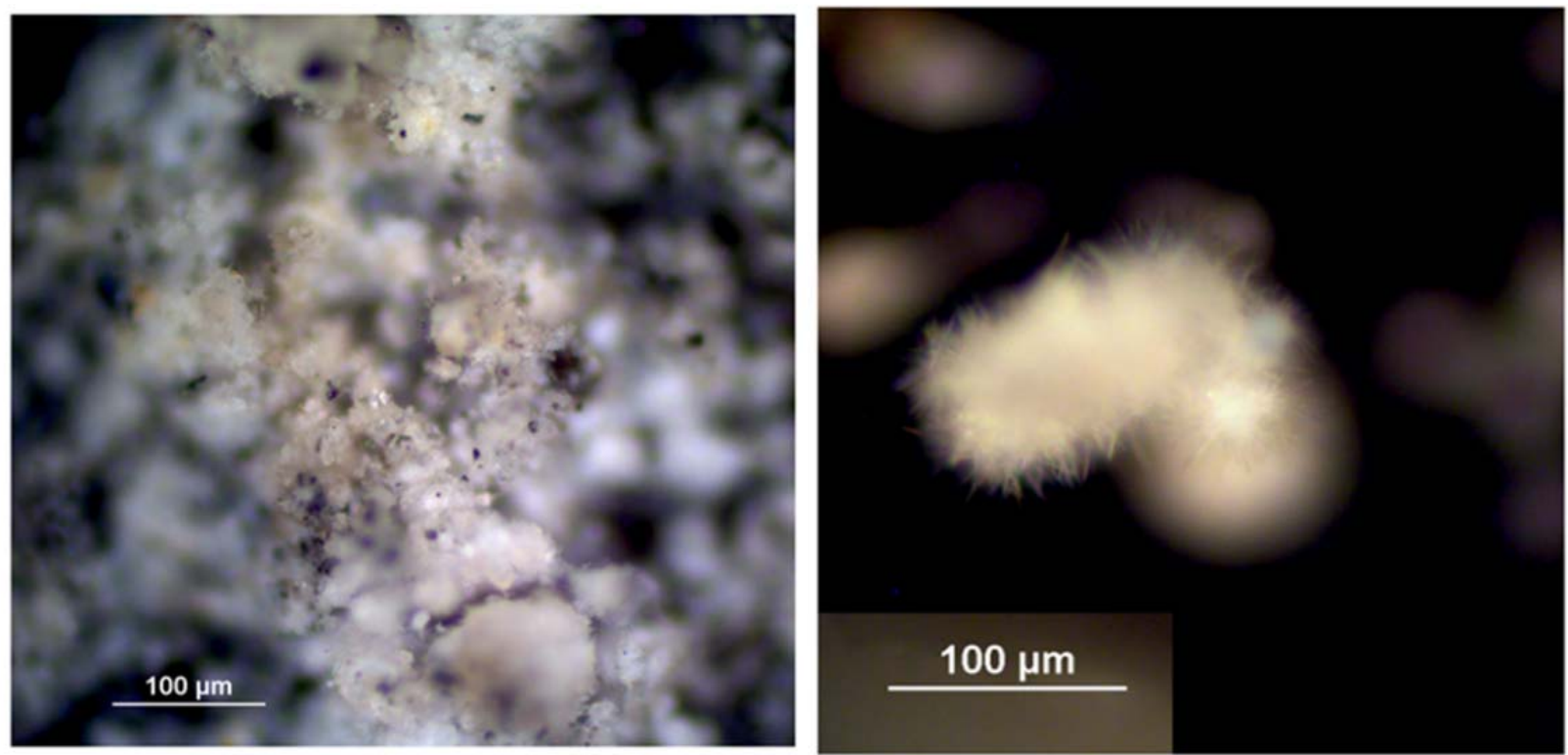

Figure 8. Polarized light microscopy image of (a) salt-like particles from R15 C5 and (b) "hairy" particle from R15 C5. 
SEM-EDS images of salt particles from R16 C4, which are thought to be similar to those pictured in the optical microscopy in Figure 8b, are pictured in Figure 9. These "hairy" sodium bearing particles were also found to be closely associated with submicron $\mathrm{Pb}$ and $\mathrm{Pu}$ particles. Based upon SEM-EDS, we believe these Na bearing particle are likely associated with $\mathrm{CO}_{3}$, which is consistent with FTIR results that identified particles of sodium carbonate (see below). The hairy like structure of the Na-bearing particles is indicative of kinetically unstable solid phases that have rapidly formed from solution. Submicron particles of $\mathrm{Pu}$ and $\mathrm{Pb}$ are closely associated with these hair-type of particles (See Figures 10 and 11). The $\mathrm{Pu}$ and U-bearing particles were not associated with the $\mathrm{MgO}$ indicating the $\mathrm{MgO}$ on the lip of R16 C4 did not come from inside the drum (but from the broken super sack).

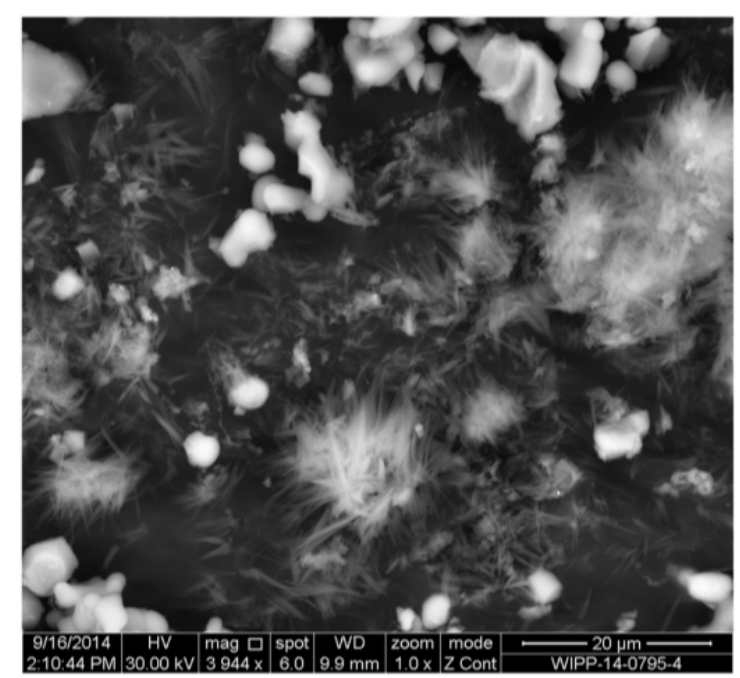

Figure 9. SEM analysis of salt particles from R16 C4.
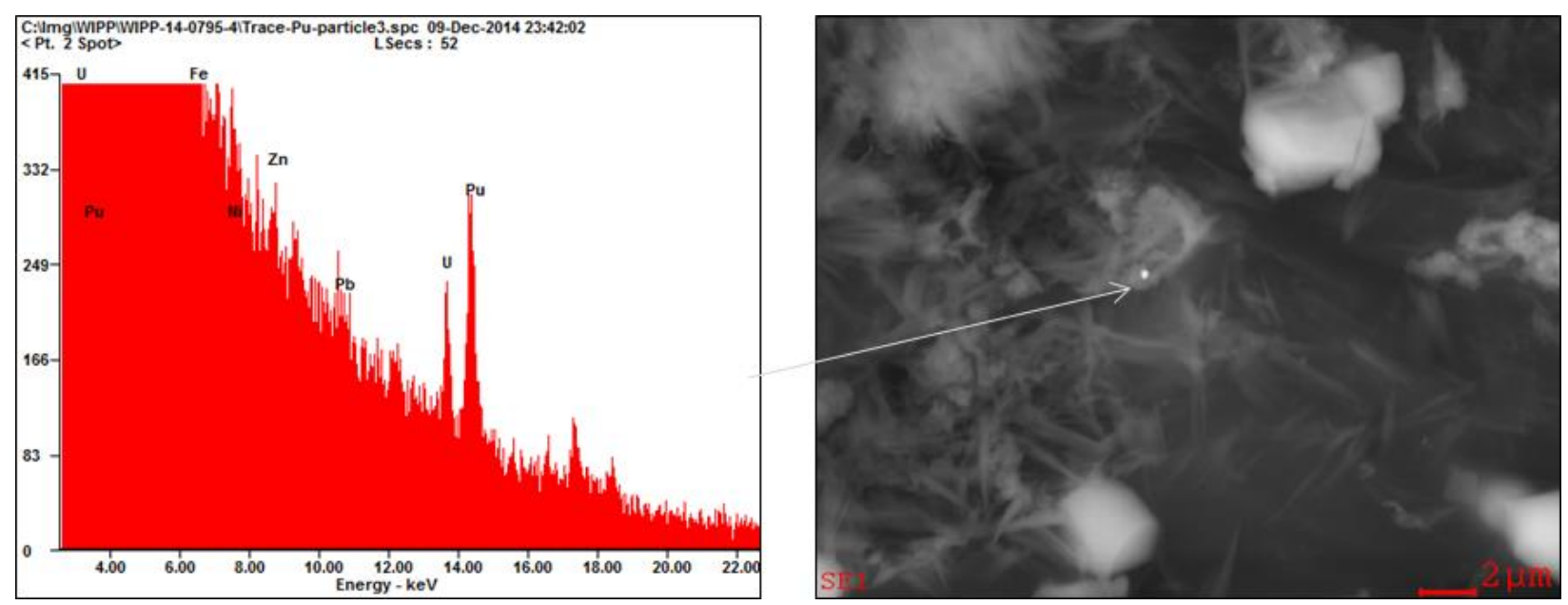

Figure 10. SEM-EDS of small Pu particle associated with hairy salt particle from R16 C4. 

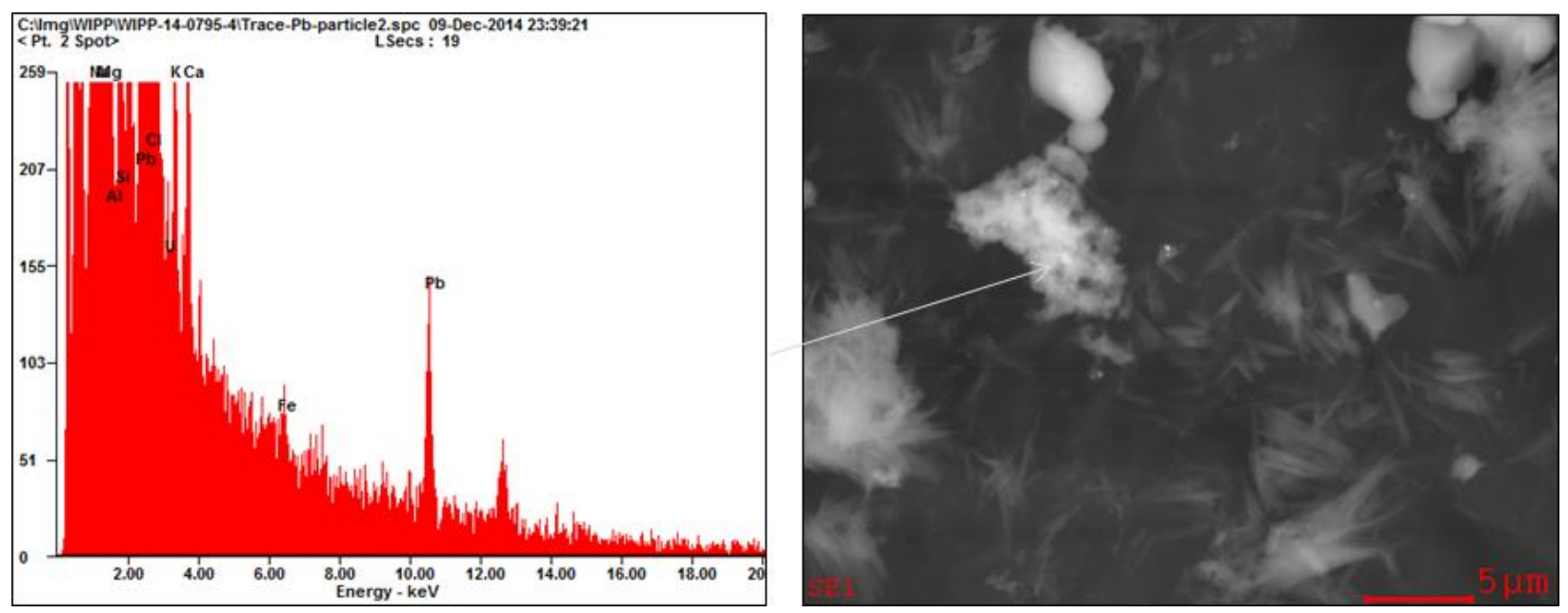

Figure 11. SEM-EDS of a small particle of $\mathrm{Pb}$ associated with the hairy salt particle from R16 C4.

Conclusion: High concentration of $\mathrm{Pb}$ found in the debris was attributed to nitric acid leaching of the lead liner in the parent during over the 28 years before processing. Other metals detected were consistent with the known content of the waste stream. Phosphorous can be used as an indicator for the presence of Swheat Scoop ${ }^{\circledR}$ since it is not found in high concentration in the waste stream. Some of the sodium containing salt particles in the debris have a morphology consistent with rapid precipitation from solution. This could have occurred as the liquids were ejected from 68660.

3.3 Glovebox Glove Did Not Participate in the Oxidations Reactions: It was proposed that the metals ( $\mathrm{Bi}, \mathrm{W}$, and $\mathrm{La}$ ) in a tungsten-lined glovebox glove, which was added to drum 68660 as process waste, could be a reaction initiator. LANL studies showed that a piece of tungsten-lined glovebox glove in concentrated nitric acid with Swheat Scoop ${ }^{\circledR}$ and $\mathrm{NaNO}_{3}$ provided a low temperature exotherm around $100{ }^{\circ} \mathrm{C}$ in a DSC experiment. [Clark, 2015] Real-time radiography of Drum 68660 at LANL confirmed that a glove was in the bottom job control solid waste layer (Figure 12). The glove appears to be near the interface of the job control solid waste layer and the neutralized liquid/Swheat Scoop ${ }^{\circledR}$ layer, but there appears to be a "barrier" between the glove and the neutralized liquid/Swheat Scoop ${ }^{\circledR}$, i.e., discarded plastic within the job control waste layer.
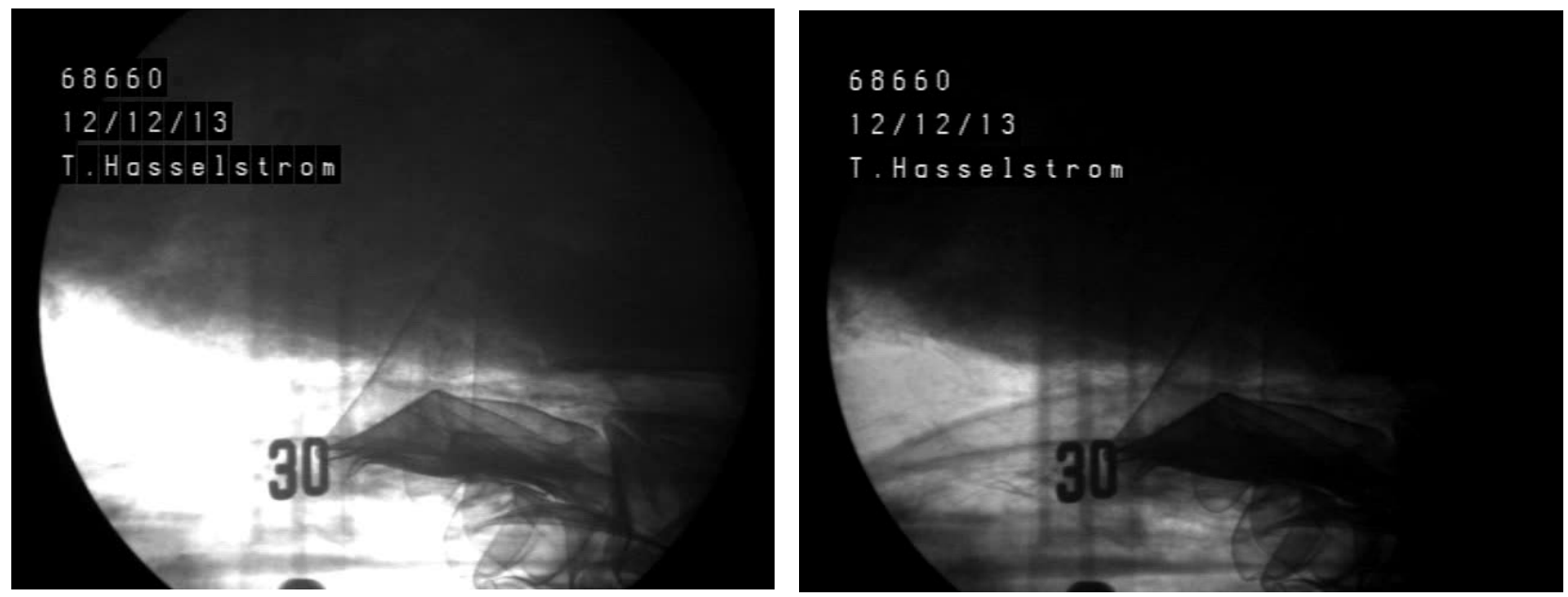

Figure 12. Radiograph of trash layer in drum 68660 showing the glovebox glove. 
Although the exact concentration of metals in the gloves are proprietary, from the company's patent on radiation attenuation elastomeric materials [Larmigny, 2012], it can be determined that the inorganic matrix contains 70-90 wt\% bismuth trioxide $\left(\mathrm{Bi}_{2} \mathrm{O}_{3}\right)$ (with a preferable composition of $80 \pm 2 \mathrm{wt} \%$ ) and 5$15 \mathrm{wt} \%$ of tungsten trioxide $\left(\mathrm{WO}_{3}\right)$ and lanthanum oxide $\left(\mathrm{La}_{2} \mathrm{O}_{3}\right)$ (with a preferable composition of $10 \pm 1$ wt $\%$ for each oxide). The preferred size range of the oxides is from 1 to 100 micrometers, with $80 \%$ of the particles less than 50 micrometers. The mass of the neoprene elastomer represents 15 to $35 \mathrm{wt} \%$ of the layer within the glove construction with the remaining 65 to $85 \mathrm{wt} \%$ composed of the inorganic oxides. The metal oxide/elastomer layer is inserted between two other elastomeric layers in the final glove. An order of magnitude calculation on the mass of rubber and inorganic oxide in one glove is: $\sim 300 \mathrm{~g}$ of rubber, $100-125 \mathrm{~g} \mathrm{Bi}_{2} \mathrm{O}_{3}, 10-13 \mathrm{~g} \mathrm{WO}_{3}$ and 9.5-12.5 $\mathrm{g} \mathrm{La}_{2} \mathrm{O}_{3}$. Since the mass of the contents of the drum is $82.3 \mathrm{Kg}$ (Thermal Model), the $\mathrm{wt} \% \mathrm{Bi}, \mathrm{W}$, and La in the drum is approximately $0.12 \mathrm{wt} \%$, $0.012 \mathrm{wt} \%$, and $0.011 \mathrm{wt} \%$, respectively. If the gloves were involved in the oxidation reactions, it is proposed that the metals would be ejected and found in the debris on R15 C5, the lip of R16 C4 or on the CAM filters. ICP-OES and ICP-MS analysis of the two R15 C5 samples and the sample from the lip of R16 C4 showed no Bi, W or La within detection limits (ppm). SEM-EDS and micro-XRF analysis of over 100 randomly selected particles from R15 C5 showed no Bi, W, or La. However, one bismuth particle was found on the lip of R16 C4 by SEM-EDS analysis but no W and La was observed (see Figure 13). Additional analysis did not find any other Bi particles. Micro-XRF analysis of the Velcro tape sample containing particles from R15 C5 did not reveal any Bi, W, or La particles. ICP-MS analysis of the CAM filters also did not show any Bi, $\mathrm{W}$, or La particles. Thus, it is unlikely that the tungsten-lined glovebox glove participated in the reaction because of the physical separation of the glove from the waste in the bottom (job control solid waste layer) of the drum and the lack of significant analytical evidence for $\mathrm{Bi}, \mathrm{W}$, or La found in the collected samples.

Conclusion: The glovebox glove did not participate in the reaction in drum 68660 because it was physically separated from the Swheat Scoop ${ }^{\circledR}$ processed liquid layer and $\mathrm{Bi}, \mathrm{W}$, or La was not found in R15 C5 or the CAM filters. The metals in the glove were in high enough concentration that they should have been seen if they were ejected from the drum.

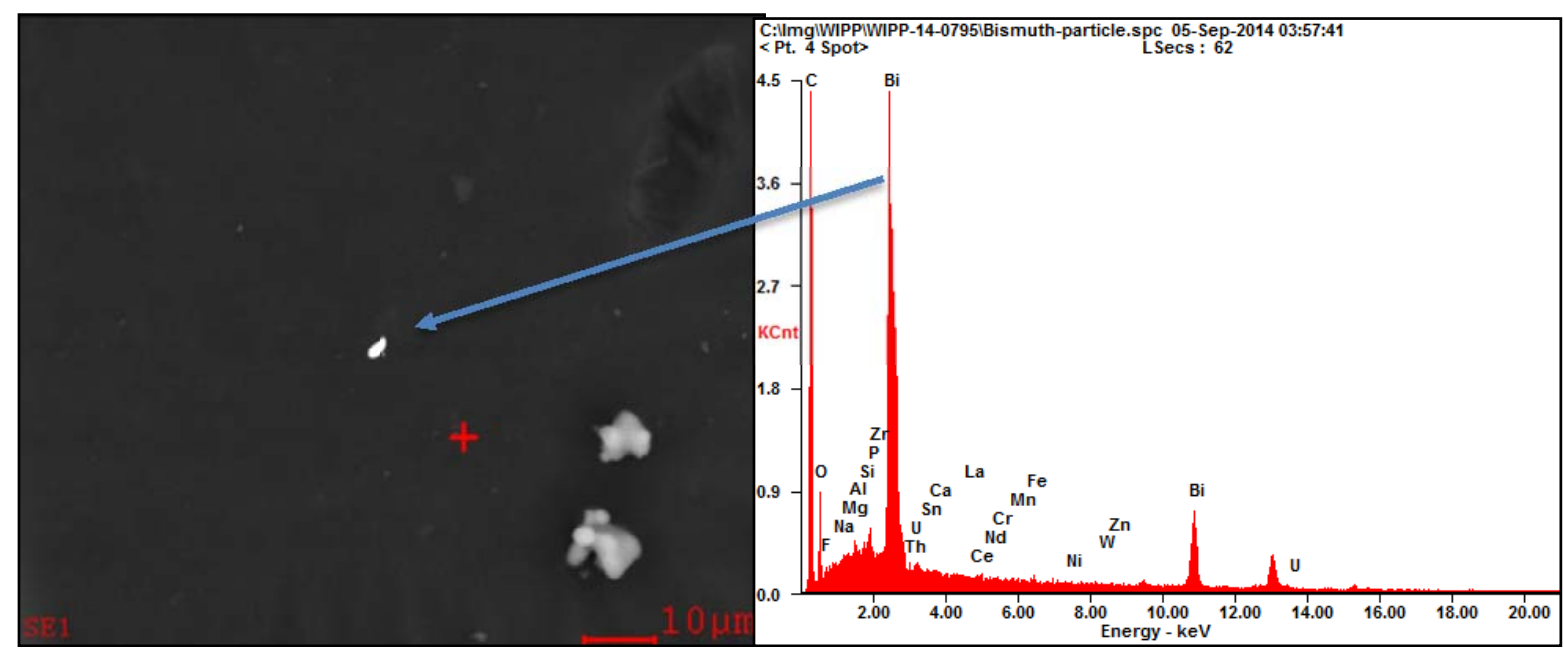

Figure 13. SEM-EDS analysis of sample from the lip of R16 C4 showing a bismuth particle.

3.4 Reaction Products from Metal Nitrate Salt Oxidation of Swheat Scoop ${ }^{\circledR}$ : The debris found on R15 C5 and the material on the lip of R16 C4 were analyzed to determine if any reaction products (described above) could be found to support the proposed reaction pathways. X-ray diffraction (XRD) analysis of a ground sample of the debris from R15 C5 was measured and search match identification was preformed 
with Jade software from Materials Data Inc. and the International Centre of Diffraction Database (see Figure 14). The sample was found to contain $\mathrm{NaNO}_{3}$ (nitratine), $\mathrm{MgO}$, and $\mathrm{Na}_{3} \mathrm{H}\left(\mathrm{CO}_{3}\right)_{2} \cdot 2 \mathrm{H}_{2} \mathrm{O}$ (Trona). Ion chromatography (IC) analysis of a water extract of the debris from R15 C5 also showed carbonate (but not quantitated by IC because of the peak shape and resolution) and nitrate (34,600 $\mathrm{mg} / \mathrm{Kg}$ ) in addition to nitrite $(13,100 \mathrm{mg} / \mathrm{Kg})$ and oxalate $(13,100 \mathrm{mg} / \mathrm{Kg})$. The total inorganic carbon in the water extract of R15 C5, determined by acidification and sparging using a Total Carbon Analyzer, was 43,600 $\mathrm{mg} / \mathrm{Kg}$ while the Swheat Scoop ${ }^{\circledR}$ water extraction and water blanks only contained $342 \mathrm{mg} / \mathrm{Kg}$ and 389 $\mathrm{mg} / \mathrm{Kg}$ inorganic carbon. The water extract was also basic ( $\mathrm{pH} 10.8)$. Sodium carbonate and nitrite salts were not present in the original waste stream, nor were they present in the $\mathrm{MgO}$ from the super sacks (see

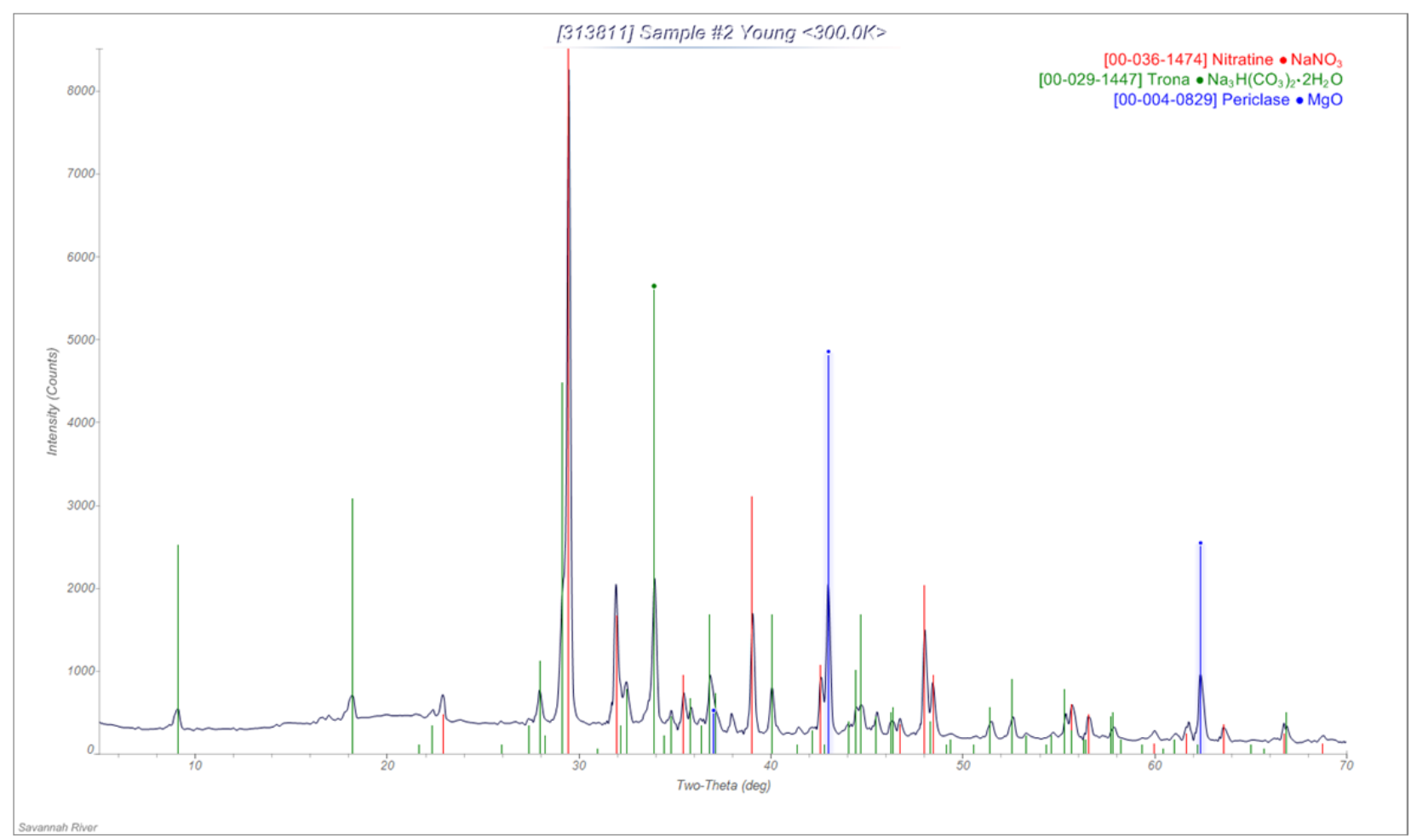

Figure 14. XRD analysis of the R15 C5 sample.

discussion on $\mathrm{MgO}$ ), or in the Swheat Scoop ${ }^{\circledR}$ and are believed to be a product from the reaction of nitrate salts with Swheat Scoop ${ }^{\circledR}$.

The origin of the MgO in the debris from R15 C5 is less clear. MgO could arise from the broken super sack or from the thermal degradation or chemical degradation of the $\operatorname{Mg}\left(\mathrm{NO}_{3}\right)_{2}$. From the pictures of the orientation of the debris on top of SWB R15 C5, it is unlikely that the majority of the MgO is from the super sack. $\mathrm{Mg}\left(\mathrm{NO}_{3}\right)_{2}$ can thermally decompose to form $\mathrm{MgO}$ but temperatures above $325^{\circ} \mathrm{C}$ are needed. Since it is known that $\mathrm{Mg}\left(\mathrm{NO}_{3}\right)_{2}$ can oxidize organics, [Cembella, 1986; Desai, 1972; Wu, 1986] the $\mathrm{MgO}$ in the debris from R15 C5 most likely arises from the $\mathrm{Mg}\left(\mathrm{NO}_{3}\right)_{3}$ oxidation of Swheat Scoop ${ }^{\circledR}$.

Conclusion: The material ejected from drum 68660 was from the metal nitrate salt oxidation of Swheat Scoop ${ }^{\circledR}$. Carbonate and nitrite were not found in the original waste stream and are known oxidation product from the reaction of nitrate salts with carbohydrates.

3.5 Reactions Inside 68660 Did Not Go to Completion: TG-MS analysis (under argon) of the debris from R15 C5 shows weight loss starting at $70{ }^{\circ} \mathrm{C}$ and a total weight loss of 9.4\%, $11.4 \%, 17.3 \%, 26.6 \%$ and $35.1 \%$ at $200,300,400,500$ and $1000{ }^{\circ} \mathrm{C}$, respectively (Figure 15). If the sample had experienced 
temperatures above $200{ }^{\circ} \mathrm{C}$ in the drum, no weight loss should be seen until after $200{ }^{\circ} \mathrm{C}$. Mass spectrometry analysis of the evolved gases below $400{ }^{\circ} \mathrm{C}$ showed $\mathrm{m} / \mathrm{z} 16\left(\mathrm{CH}_{4}\right), \mathrm{m} / \mathrm{z} 18\left(\mathrm{H}_{2} \mathrm{O}\right), \mathrm{m} / \mathrm{z} 44$ $\left(\mathrm{CO}_{2}\right.$ and/or $\left.\mathrm{N}_{2} \mathrm{O}\right), \mathrm{m} / \mathrm{z} 30\left(\mathrm{NO}\right.$ and $\left.\mathrm{CH}_{2} \mathrm{O}\right)$ and $\mathrm{m} / \mathrm{z} 46\left(\mathrm{NO}_{2}\right)$ were present which is consistent with the decomposition of organics and nitrate salts (Figure 16). Since $\mathrm{m} / \mathrm{z} 30$ is the base peak (i.e., $100 \%$ abundance) for $\mathrm{NO}_{2}$ in the mass spectrum and $\mathrm{m} / \mathrm{z} 30$ and 46 peaks do not overlay, it indicates another material is responsible for the $\mathrm{m} / \mathrm{z} 46$ peak at temperatures below $150{ }^{\circ} \mathrm{C}$. Oxygen $(\mathrm{m} / \mathrm{z} 32)$ evolution starts at $560{ }^{\circ} \mathrm{C}$ and reaches a maximum at $620^{\circ} \mathrm{C}$ consistent with decomposition of $\mathrm{NaNO}_{3}$. The TG-MS results indicate that the materials ejected from the drum either did not experience temperatures over 200 ${ }^{\circ} \mathrm{C}$ or that their exposure to elevated temperature was very limited in duration (<seconds). If the oxidation reactions occurred in the middle of the drum, for example, pressure could build up from the gaseous products and eject the unreacted top layer of Swheat Scoop ${ }^{\circledR} /$ nitrate salt out of the drum. Nitrate (3.5 $\mathrm{wt} \%)$, nitrite (1.3 wt\%), and oxalate (1.3 wt\%) salts were found in the debris on R15 C5 as well as on the CAM filters consistent with the salt layer being ejected. Since magnesium and calcium nitrite salts are unstable above $400^{\circ} \mathrm{C}$ [Stern, 1972; Oza, 1950] and magnesium and calcium oxalate salts are unstable above $500{ }^{\circ} \mathrm{C}$ [Gadalla, 1984], this indicates that the reaction temperature in the drum did not exceed these temperatures for an extended period. Moreover, oxalic acid starts to decomposes above $150{ }^{\circ} \mathrm{C}$ in the gas phase and its calculated half-life at $250{ }^{\circ} \mathrm{C}$ is $3 \mathrm{~s}$. [Lapidus, 1964] Thus, it can be concluded that the materials ejected from the drum either did not experience high temperatures (over $400{ }^{\circ} \mathrm{C}$ ) or that their exposure to elevated temperatures was very limited in duration (<seconds) resulting in the observation of nitrite and oxalate salts in the collected samples. LC-MS data are consistent with presence of triethanolamine, further supporting that reactions did not go to completion.

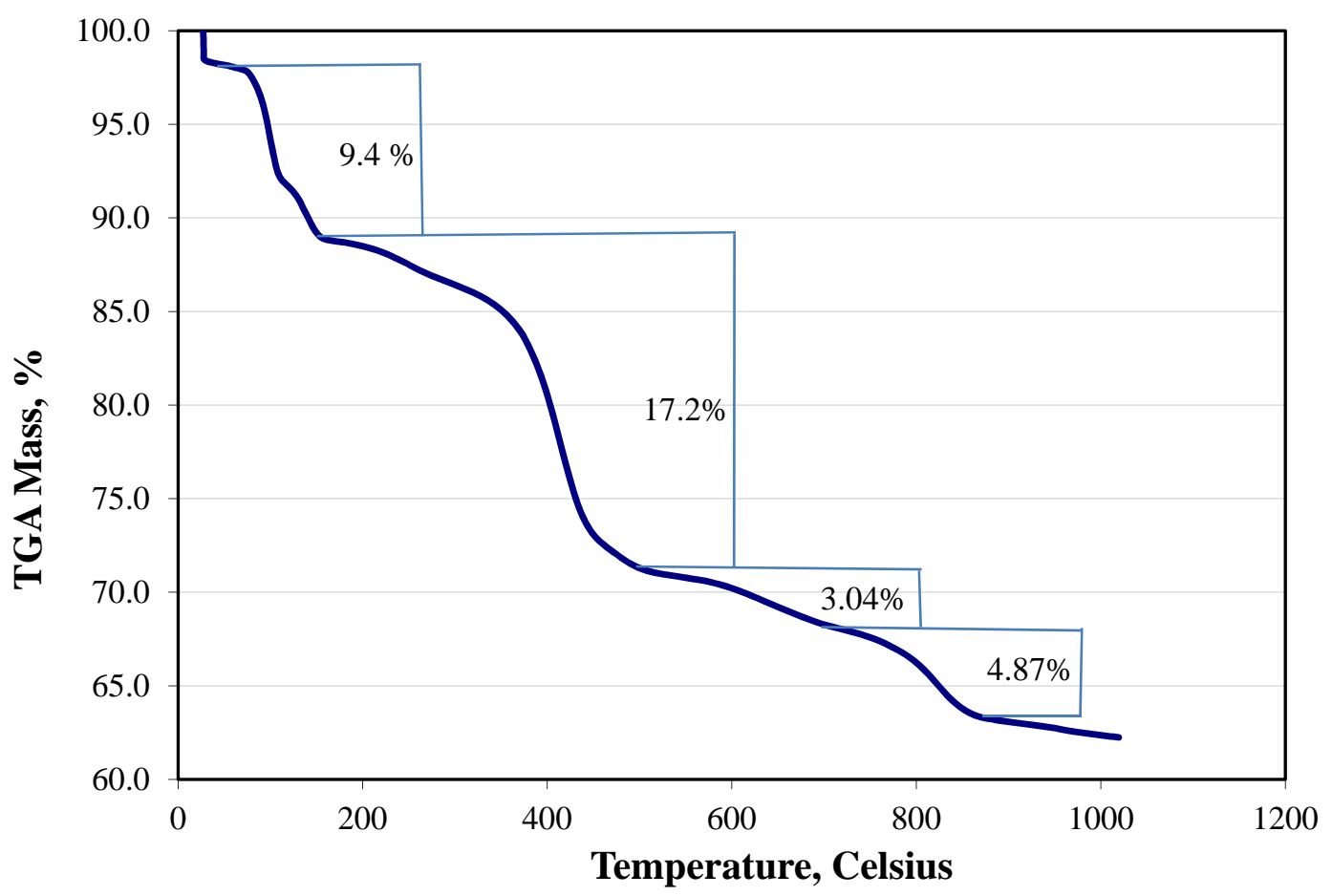

Figure 15. TG-MS analysis of debris from R15 C5 under argon. 


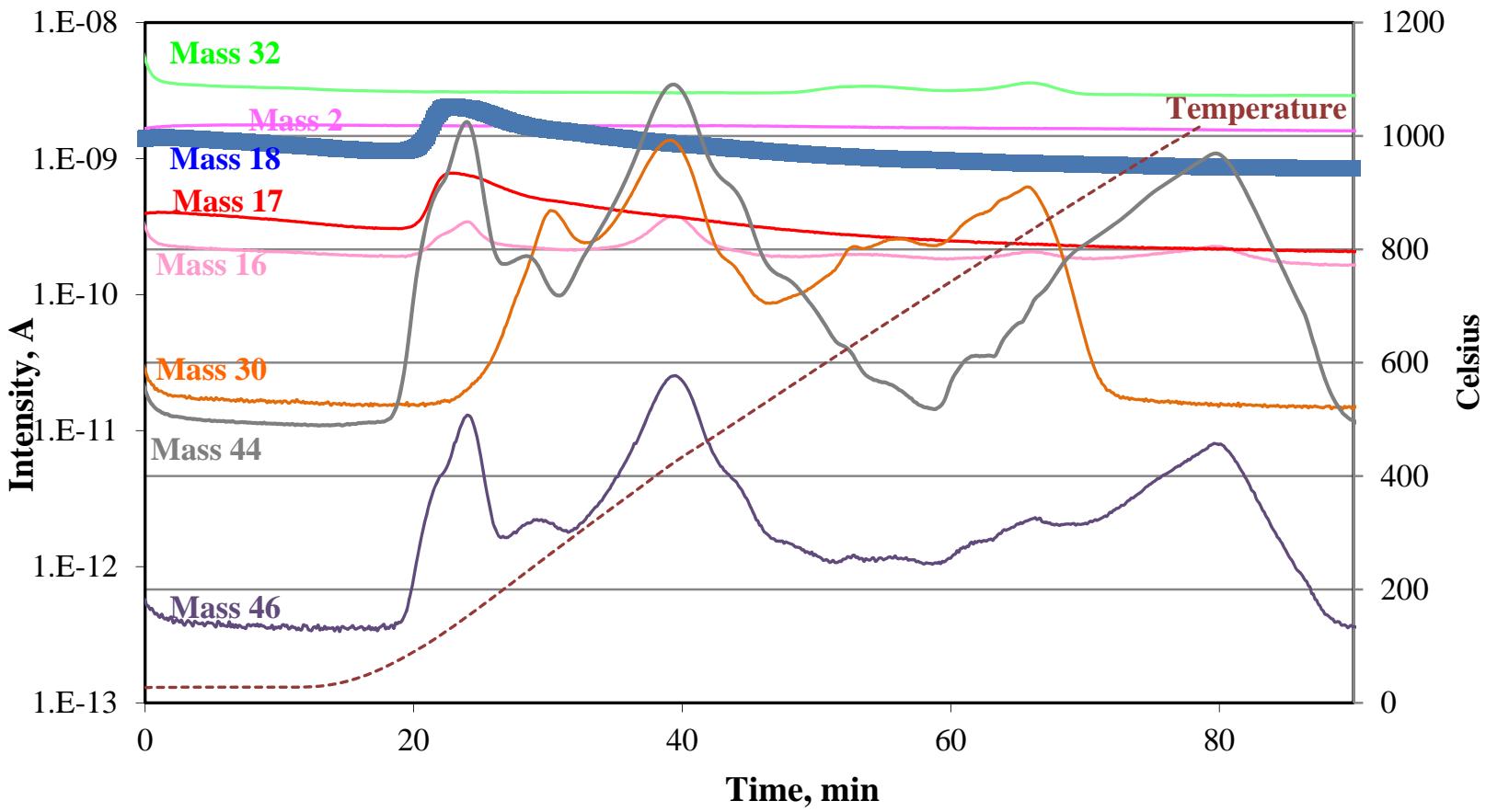

Figure 16. MS analysis of the evolved gases from the decomposition of R15 C5 under argon.

Conclusion: The reactions inside drum 68660 did not go to completion and the material ejected from the drum did not experience temperatures over $200{ }^{\circ} \mathrm{C}$ or their exposure to elevated temperatures was of short duration (seconds). This hypothesis is supported by the unreacted material and thermally sensitive materials found in the debris.

3.6 Oxidation Products Found in Debris but Nitration Products Were Not Detected: From the reaction chemistry discussed above, oxidation and nitration products from Swheat Scoop ${ }^{\circledR}$ are predicted. To analyze for these materials, the debris from R15 C5 was placed between KBr discs and analyzed by FTIR microscopy (Figure 17). The FTIR spectra are very complex and show a mixture of organic materials (identified by C-H stretches centered at $2935 \mathrm{~cm}^{-1}$ ) and inorganic materials. By comparing the results from SEM-EDS, XRD, and IC with the FTIR spectra, the data is consistent with a mixture of Swheat Scoop ${ }^{\circledR}$ (or other carbohydrates) with nitrate, nitrite, oxalate, and carbonate salts. The broad peak at $3000-3700 \mathrm{~cm}^{-1}$ is from hydroxyl groups and hydrogen bonded hydroxyls (and water) associated with the organics or inorganic salts. Amines (N-H stretches) also come in this region (3200-3400 $\left.\mathrm{cm}^{-1}\right)$ and they have additional N-H bends and C-N stretches between 1000-1600 $\mathrm{cm}^{-1}$. Nitrate salts (Na, K, Ma, Ca, $\mathrm{Fe}$, and $\mathrm{Pb}$ ) all have very strong bands at $1350-1380 \mathrm{~cm}^{-1}$ and weaker bands at $815-835 \mathrm{~cm}^{-1}$ (while nitrate salts with divalent cations have an additional strong peak at 1430-1480 $\mathrm{cm}^{-1}$ ).[ Miller, 1952] Nitrite salts have very strong bands at $1235-1250 \mathrm{~cm}^{-1}$ and medium intensity bands at $1328-1380$ and $820-835 \mathrm{~cm}^{-1}$. Carbonates have very strong stretches at $1410-1450 \mathrm{~cm}^{-1}$. [ Miller, 1952] Oxalate salts (Na, Ca, Mg, and $\mathrm{K}$ ) have very strong stretches at $1605-1640 \mathrm{~cm}^{-1}$ and $1320-1370 \mathrm{~cm}^{-1}$ [Pedersen, 1967] while salts of aliphatic carboxylates have strong stretches at $1538-1580 \mathrm{~cm}^{-1}$ and $1405-1470 \mathrm{~cm}^{-1}$. All these peaks are found in the spectra. The small peak at $2174 \mathrm{~cm}^{-1}$ could be from a nitrile group and will be discussed in more detail later. 


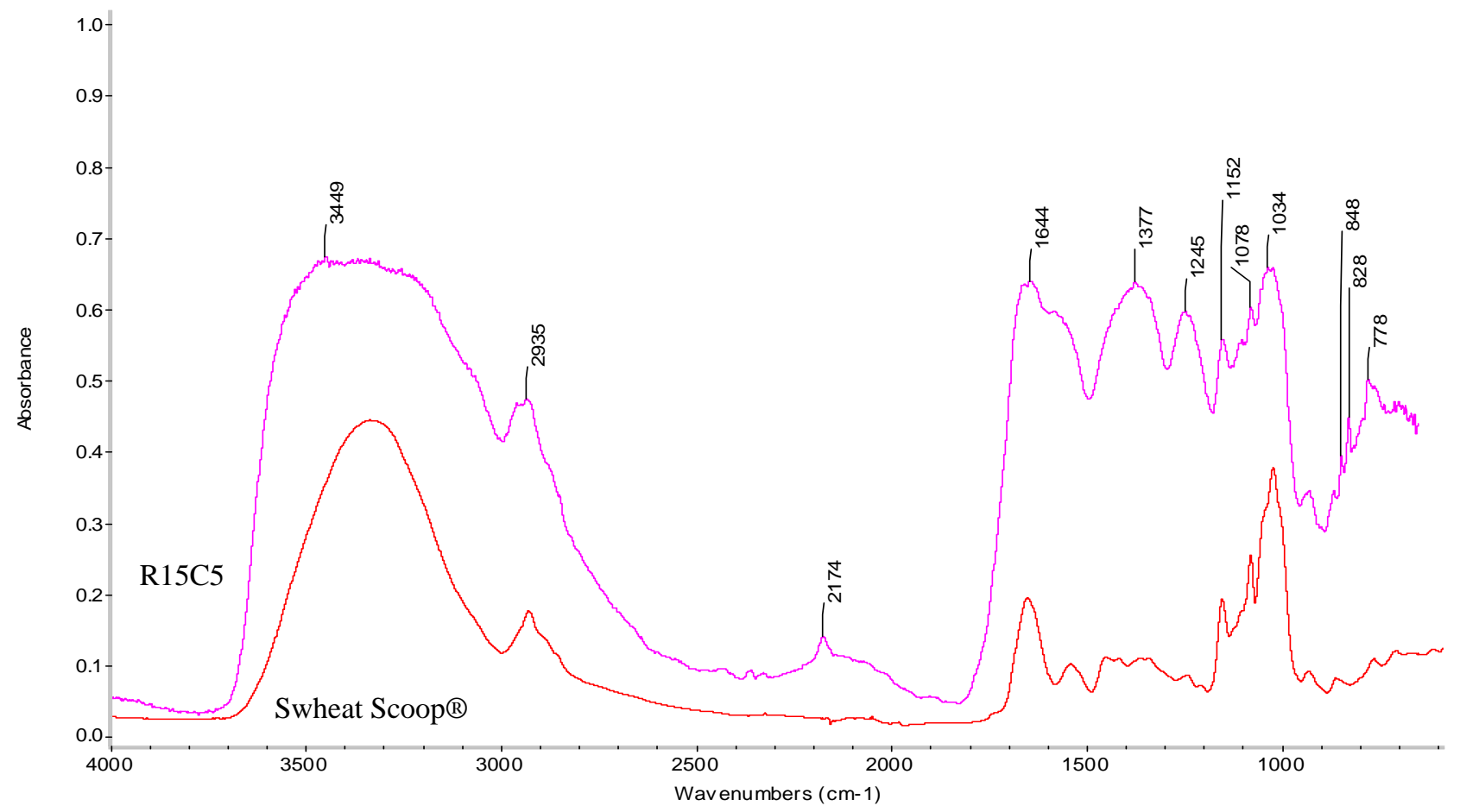

Figure 17. FTIR spectra of the solid R15 C5 sample compared to Swheat Scoop ${ }^{\circledR}$.

FTIR microscopy of particles from the lip of R16 C4 showed similar spectra containing a mixture of inorganic and organic materials. For example, FTIR microscopy of the black particle in Figure 18a has spectral signatures indicative of an aliphatic carboxylic acid $\left(1703 \mathrm{~cm}^{-1}\right)$, carboxylate salts $\left(1581 \mathrm{~cm}^{-1}\right)$, nitrates, nitrites, carbonates, and nitrile $\left(2214 \mathrm{~cm}^{-1}\right)$. The upper spectrum (and optical microscope image) is consistent with nylon from the Velcro (showing N-H stretch at $3298 \mathrm{~cm}^{-1}$ and amide bands at $1637 \mathrm{~cm}^{-1}$ and $1537 \mathrm{~cm}^{-1}$ ).

It is difficult to determine if nitrate esters, which have characteristic $\mathrm{NO}_{2}$ stretches at $1625-1660 \mathrm{~cm}^{-1}, 1275-1380 \mathrm{~cm}^{-1}$, and 840$880 \mathrm{~cm}^{-1}$ [Suppes, 2003; López-Lópeza, 2010] and aliphatic nitro group, which have stretches at 1540-1575 $\mathrm{cm}^{-1}$, and 1350-1375 $\mathrm{cm}^{-1}$, [Lambert 1987] are present in the sample because these peaks overlap with other materials in the sample. The FTIR spectrum of nitrocellulose is shown in Figure 19 to highlight the strong $\mathrm{NO}_{2}$ bands at 1660 and $1280 \mathrm{~cm}^{-1}$, and NO stretch at $840 \mathrm{~cm}^{-1}$ compared to cellulose. If nitrate esters were in high concentrations, they could be easily observed by FTIR (or Raman spectroscopy).

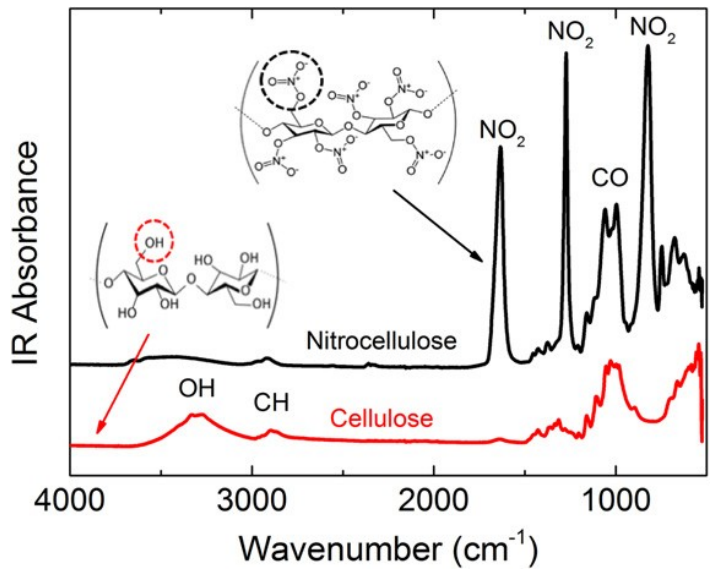

Figure 19. FTIR spectra of cellulose (chromatography paper) and nitrocellulose at room temperature. [Coatas, 2014] 


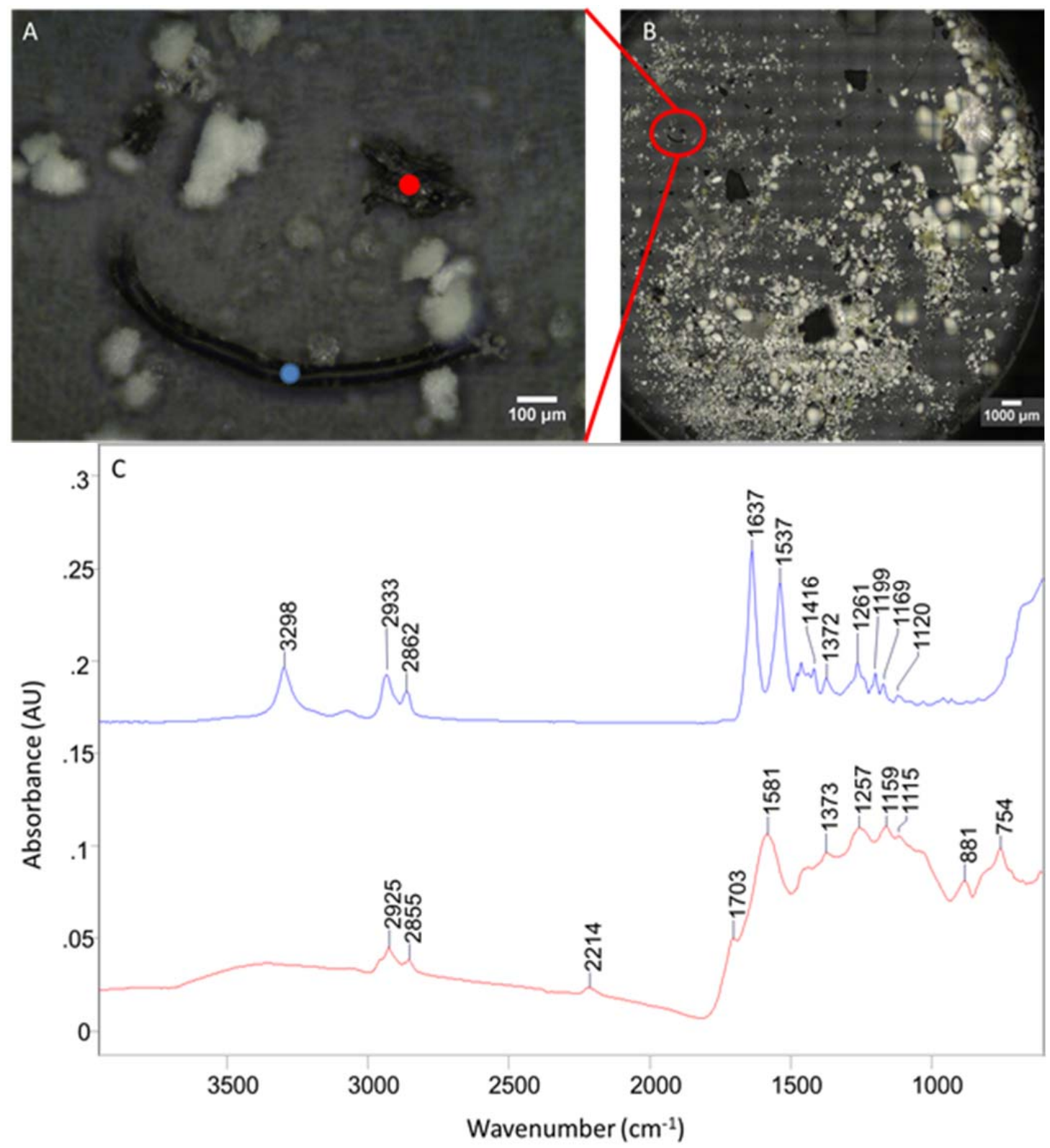

Figure 18. (a) Pictures of where ATR-IR data was collected on black particle 4 (blue dot) and black particle 5 (red dot) in subsample R16 C4. (b) Overview picture of subsample R16 C4, loose powder that was collected from the Swiffer sampler that was landed near the lip of the drum that ruptured (R16 C4). (c) IR spectra of black particle 4 (blue) and black particle 5 (red).

Particles of R15 C5 stuck to the Velcro tape were analyzed by Raman microscopy using an incident frequency of $1064 \mathrm{~nm}$. Many attempts were made to visually identify and measure particles that could yield useful Raman spectra, i.e., particles that were not black. These particles included tan and bluishgray particles and particle aggregates of varying sizes. These particles and aggregates were interrogated with the very lowest levels of laser power that were required to maintain a stable laser beam. The results of the Raman analyses did not provide any useful vibrational information about the residues. Instead, spectra from the WIPP samples were overwhelmed with blackbody emission and sometimes with fluorescence emission. In many cases, the interrogated particles were obliterated from the surface of the Velcro adhesive backing when exposed to the excitation laser. 
The debris from R15 C5 was also extracted with $\mathrm{CH}_{2} \mathrm{Cl}_{2}$ and the solvent evaporated onto $\mathrm{KBr}$ discs and analyzed by FTIR microscopy to look for nitrated or oxidized organics. A representative spectrum is shown in Figure 20. The sample contains organic residue (C-H stretches present 2960 and $2876 \mathrm{~cm}^{-1}$ ) and potentially carboxylic acids or esters based on the peaks above $1700 \mathrm{~cm}^{-1}$. Carboxylic acids have been observed from the nitrate salt oxidation of lignocellulosic materials and the carbonyl bands appeared around 1700-1725 $\mathrm{cm}^{-1}$. [Wu, 1986] Oxalic acid has $\mathrm{C}=\mathrm{O}$ stretches at $1745 \mathrm{~cm}^{-1}$ and O-C-O stretch at $1224 \mathrm{~cm}^{-1}$ while the mono $\left(1745,1623,1394,1245 \mathrm{~cm}^{-1}\right)$ and dicarboxylate salts $\left(1569,1305 \mathrm{~cm}^{-1}\right)$ have stretches at lower frequencies. [Jung, 2003] The peaks above $3100 \mathrm{~cm}^{-1}$ can be attributed to -OH from acids or alcohols, hydrogen bonded water or amines. The peaks at 1227,1133 and $1069 \mathrm{~cm}^{-1}$ are an indication the sample contains carbohydrates, since typical C-O stretches in carbohydrates are found between 1000-1250 $\mathrm{cm}^{-1}$. [Tipson, 1968] As previously discussed, it is difficult to determine if nitrate esters or nitro groups are present in the sample because the characteristic stretching frequencies overlap with other materials. If nitrate esters are present, they are in low concentration. Some entrained particles were also present that had FTIR spectra similar to cellulose (see Figure 21), sodium oxalate and sodium carbonate. Although Swheat Scoop ${ }^{\circledR}$ particles are not clearly visible, there is insoluble organic material resembling Swheat Scoop ${ }^{\circledR}$ in most FTIR spectra of the samples from R15 C5, R16 C4 and the CAM filters.

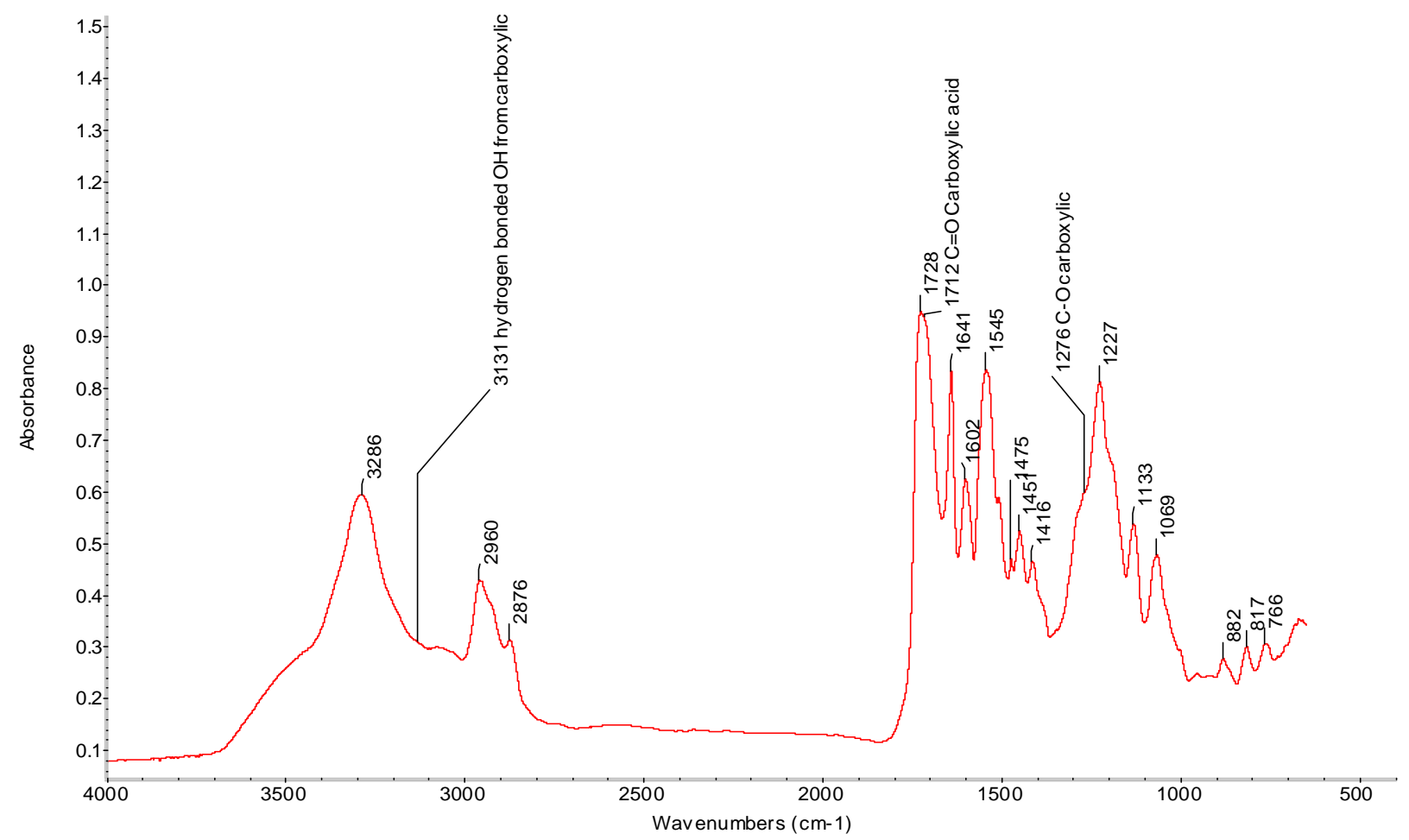

Figure 20. FTIR of the $\mathrm{CH}_{2} \mathrm{Cl}_{2}$ extract of $\mathrm{R} 15 \mathrm{C} 5$. 


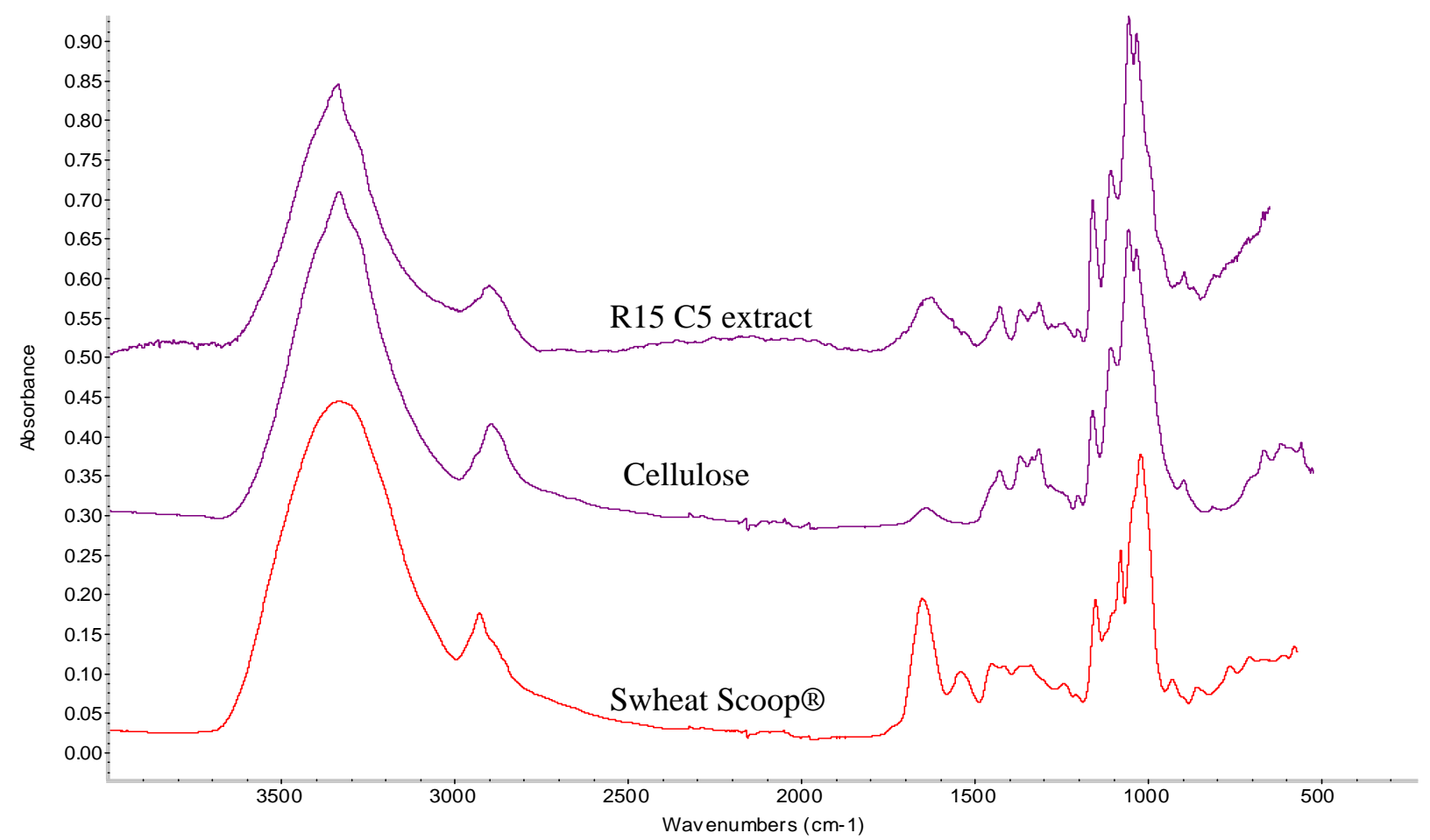

Figure 21. FTIR spectrum of a particle collected from the methylene chloride extract of R15 C5 compared to cellulose and Swheat Scoop ${ }^{\circledR}$. Particle is similar to cellulose.

The methylene chloride extracts were also analyzed by GC-MS and very few organic compounds were observed (ppm detection limits). No oxidized materials (i.e., small carboxylic acids or sugars), triethanolamine (TEA), or nitrate esters (i.e., no materials with a nitronium $\left(\mathrm{m} / \mathrm{z}=46, \mathrm{NO}_{2}{ }^{+}\right)$fragment) were observed. Since TEA is a high boiling $\left(335^{\circ} \mathrm{C}\right)$ liquid, an authentic sample was analyzed on the GC-MS, using the same method that was used for the methylene chloride extracts, to confirm its retention time and mass spectrum. Selective ion monitoring at $\mathrm{m} / \mathrm{z} 118$ (the base peak for TEA in the mass spectrum) did not find any TEA. Since many of the expected reaction products are polar (sugars, carboxylic acids, and alcohols) and might not make it through the GC, the extracts were derivatized with $\mathrm{N}$-methylbis(trifluoroacetamide) (MBTFA), which is best for trifluoroacetylating carbohydrates and sugars, and $\mathrm{BF}_{3} /$ butanol, which is best for esterifying carboxylic acids. No new materials, other than decomposition products from the reagents, were observed. Since the residue from R15 C5 was basic, some of the organics could be tied up as salts and are not extractable in organic solvent. For example, oxalate, formate, and acetate were found in the water extract of the debris but these products were not observed in the methylene chloride extract by GC-MS. A water extract of the debris from R15 C5 found organic carbon (TOC $23,280 \mathrm{mg} / \mathrm{Kg}$ ) was present in the water. However, it is known that Swheat Scoop ${ }^{\circledR}$ has cold-water solubility [Sladek, 1997] and a water extract of Swheat Scoop ${ }^{\circledR}$ contained 46,700 $\mathrm{mg} / \mathrm{Kg}$ of organic carbon. Since the water extract from R15 C5 also contained phosphate (1610 mg/Kg), Swheat Scoop ${ }^{\circledR}$ is present in the sample and could be contributing to the measured carbon.

To analyze for polar organics, the R15 C5 samples was extracted with methanol and analyzed by LC-MS using a high resolution mass spectrometer capable of tandem mass spectrometry experiments, in positive electrospray mode. Unlike, GC-MS, no LC-MS libraries are available to assist in the identification of unknown compounds; however, by exploiting exact mass measurements, the presence of targeted compounds can be detected. Using this type of targeted analysis, triethanolamine was tentatively identified in the sample. 
Conclusion: Oxidation products (i.e., carboxylic acids) were found in the debris from drum 68660 consistent with oxidation reactions but nitrated organic products were not observed in the debris from 68660 (but could not be ruled out). The gases from the nitrate salt oxidation of Swheat Scoop ${ }^{\circledR}$ can produce sufficient quantities of gas to cause the breach of 68660. Unreacted organics materials still remain in the debris from R15 C5 indicating the reaction did not go to completion.

3.7 No Products from Decomposition of TEAN Were Observed: As previously discussed, TEAN decomposes above $250{ }^{\circ} \mathrm{C}$ to gaseous products including, $\mathrm{HCN}, \mathrm{NH}_{3}, \mathrm{NO}, \mathrm{H}_{2} \mathrm{CO}, \mathrm{CH}_{3} \mathrm{CHO}, \mathrm{CO}, \mathrm{H}_{2}$, $\mathrm{CO}_{2}, \mathrm{CH}_{4}, \mathrm{C}_{2} \mathrm{H}_{4}, \mathrm{CH}_{3} \mathrm{CN}, \mathrm{N}_{2} \mathrm{O}$, and $\mathrm{NO}_{2}$, [Lee, 1999] which, due to their high volatilities, would not be observed in the debris except maybe unreacted TEA (which has a bp $335^{\circ} \mathrm{C}$ ). No TEA or TEA degradation products were observed in the methylene chloride extracts of R15 C5 but TEA was potentially identified in the LC-MS analysis. Since the debris from R15 C5 was basic, the HCN could potentially react with a base and form a cyanide salt. Nitriles have strong unique stretches in the FTIR with sodium and potassium cyanide having stretches at 2080 and $2070 \mathrm{~cm}^{-1}$ respectively, and $\mathrm{Fe}(\mathrm{CN})_{6}{ }^{3-}$ having a stretch at $2100 \mathrm{~cm}^{-1}$. [Miller, 1952] For R15 C5, R16 C4, and the CAM filter, peaks in the FTIR were observed at $2174 \mathrm{~cm}^{-1}, 2214 \mathrm{~cm}^{-1}$ and $2236 \mathrm{~cm}^{-1}$, respectively. These peaks are too high for metal cyanides and are more consistent with alkyl nitriles, which have CN stretches between $2190-2260 \mathrm{~cm}^{-1}$, [Scorates, 1994] or alkynes, which have weak stretches between $2100-2260 \mathrm{~cm}^{-1}$. The most likely origin of the nitriles is from the thermal decomposition of the proteins (ca. $14 \mathrm{wt} \%$ ) in Swheat Scoop ${ }^{\circledR}$. It is known that pyrolysis of proteins will produce nitriles. [Moldoveanu, 1998]

Conclusion: The contribution of TEAN to the beach of drum 68660 can not be determined because no unreacted TEAN or its decomposition products were observed. However, if the reaction temperature in the drum around the TEAN exceeded $250^{\circ} \mathrm{C}$, it would be consumed by exothermic degradation to gaseous products.

3.8 Low Melting Eutectic Mixture of Salts Could Form: One hypothesis is that a low melting eutectic mixture of salts was formed that increased the transport of reactive materials and accelerated the oxidation reactions. It is well known that binary or ternary mixtures of $\mathrm{Na}, \mathrm{K}, \mathrm{Ca}$, and $\mathrm{Mg}$ nitrates form low melting $\left(<150{ }^{\circ} \mathrm{C}\right)$ eutectics. [Janz, 1972] For example, a mixture of 67-71 wt $\% \mathrm{Mg}\left(\mathrm{NO}_{3}\right)_{2} \bullet 6 \mathrm{H}_{2} \mathrm{O}$, 23-26 wt\% $\mathrm{KNO}_{3}$, and 6-8 $\mathrm{wt} \% \mathrm{NaNO}_{3}$ melts at $65^{\circ} \mathrm{C}(\mathrm{Mg} / \mathrm{Na}=3.5, \mathrm{~K} / \mathrm{Na}=5)$ while a $91-94 \mathrm{wt} \%$ $\mathrm{Mg}\left(\mathrm{NO}_{3}\right)_{2} \cdot 6 \mathrm{H}_{2} \mathrm{O}$ and 6-9 $\mathrm{wt} \% \mathrm{NaNO}_{3}$ has a melting point of $83{ }^{\circ} \mathrm{C}(\mathrm{Mg} / \mathrm{Na}=4)$. [Hammond, 1998] To determine if a eutectic mixture of metal salts could be present, exact composition and concentrations of the salts would be needed since the melting point is dependent on these variables. Although the concentrations of metals from the materials on R15 C5 can be determined by ICP-OES, it is difficult to determine if the $\mathrm{Na}$ and $\mathrm{Mg}$ came from 68660 or the salt mine and broken super sacks, respectively. Nevertheless, the ratio of the primary metal ions in the two samples from R15 C5 and the sample from the parent drum was measured by ICP-OES after either mixed acid digestion or peroxide fusion. The R16 C4 lip sample was not included because the material appeared to be predominately MgO from the super sack from the photographs (see Sampling section), and SEM-EDS analsysis. The ICP-OES results are shown in Table 3 as a ratio of salts normalized to sodium along with the expected ratio of salts from the estimated contents in drum 68660 (Table 1). Although the ratio of salts varied significantly between the two R15 C5 samples, the salt ratios are in a range in which a eutectic mixture of $\mathrm{Mg}, \mathrm{Na}$, $\mathrm{Ca}$, and $\mathrm{K}$ nitrates salts could form. While the melting temperature of the potential eutectic mixture is not precisely know and will depend on the water of hydration, these results indicate that a liquefied eutectic mixture was possible in the drum environment. These numbers were also examined to help determine the ratio of salts to use in the 10-gallon drum tests. 
Conclusion: The composition and concentration of metal nitrate salts in drum 68660 were in a range where a low melting eutectic mixture could form which would accelerate the oxidation reactions.

Table 3. Ratio of metal cations relative to sodium from the debris on R15 C5 and the parent drum.

\begin{tabular}{|c|c|c|c|c|}
\hline & 68660 & $\mathrm{R} 15$ C5 Sample 2 & $\mathrm{R} 15 \mathrm{C5}$ Sample 3 & Parent Drum \\
\hline Component $(\mathrm{X})$ & $\mathrm{X} / \mathrm{Na}$ & $\mathrm{X} / \mathrm{Na}$ & $\mathrm{X} / \mathrm{Na}$ & $\mathrm{X} / \mathrm{Na}$ \\
\hline $\mathrm{Mg}$ & 1.6 & 0.60 & 3.2 & 0.18 \\
\hline $\mathrm{Na}$ & 1.0 & 1.0 & 1.0 & 1.0 \\
\hline $\mathrm{Ca}$ & 0.26 & 0.015 & 0.083 & 0.075 \\
\hline $\mathrm{Fe}$ & 0.11 & 0.005 & 0.017 & 0.26 \\
\hline $\mathrm{K}$ & 0.18 & 0.042 & 0.12 & 0.16 \\
\hline
\end{tabular}

\section{MgO Did Not React with $\mathrm{CO}_{2}$ or $\mathrm{H}_{2} \mathrm{O}$}

If $\mathrm{MgO}$ in the super sacks reacted with $\mathrm{CO}_{2}$ and $\mathrm{H}_{2} \mathrm{O}$ from the truck fire, the products of this reaction would be $\mathrm{Mg}(\mathrm{OH})_{2}$ (brucite), $\mathrm{MgCO}_{3}$ (magnesite) and potentially other metastable hydrous carbonates including $\left(\mathrm{Mg}_{5}\left(\mathrm{CO}_{3}\right)_{4}(\mathrm{OH})_{2} \bullet 4 \mathrm{H}_{2} \mathrm{O}\right)$ (hydromagnesite), $\mathrm{Mg}_{2} \mathrm{CO}_{3}(\mathrm{OH})_{2} \bullet 3 \mathrm{H}_{2} \mathrm{O}$ (artinite), and $\mathrm{MgCO}_{3} \bullet$ $\mathrm{H}_{2} \mathrm{O}$ (nesquehonite). These reactions are exothermic and the products have a lower bulk density than $\mathrm{MgO}$ and could cause the super sack to expand and break. To investigate this scenario, samples of MgO were obtained from WIPP and analyzed for products from the hydration and/or carbonation of MgO. The rates and heat of hydration were also determined (Room External Model Report) and found to be too low to generate enough heat to melt the polypropylene (i.e., super sack) bags.

4.1 MgO Samples: MgO samples were collected from the broken super sacks on top of waste drums R14 C2, R14 C4, and R14 C6 in Room 7 of Panel 7 on May 30, 2014 with a PVC pipe type collection apparatus as previously discussed. The samples contained powder and small pellets as shown in Figure 22. An addition MgO sample was also taken from the top of R16 C4 using a multi-sampler device constructed from a Swiffer ${ }^{\circledR}$ head containing 4 disc smears, a Velcro strip and a Velcro strip with the adhesive tape exposed (as described in the Sampling Integrated Summary Report in Appendix B, see Figure 23). Low levels of Am-241 were found by gamma analysis for R14 C2 (1100 dpm), R14 C4 (1200 dpm), R14 C6 (<260 dpm) and R16 C4 (3700 dpm). Results of this analysis were qualitative since calibrated geometries for these samples were not available. Interestingly, the R14 C6 sample had the lowest activity even though the material ejected from R16 C4 would have moved toward R14 C6. However, if the material (and radioactivity) was quickly released from R16 C4 in the direction of the super sack on top of R14 C6 and caused the super sack to fail, then most of the radioactivity would be buried under the $\mathrm{MgO}$ and relatively clean $\mathrm{MgO}$ from the interior of the super sack would be exposed and sampled. Since all of the $\mathrm{MgO}$ samples from the top of the waste drums had low levels of radioactivity, this implies that the radioactive release was fast and the airflow carried the materials out of Room 7. If radioactive material was slowly released (i.e., over minutes) from drum 68660, more radioactivity would have deposited on the surrounding $\mathrm{MgO}$ sacks.

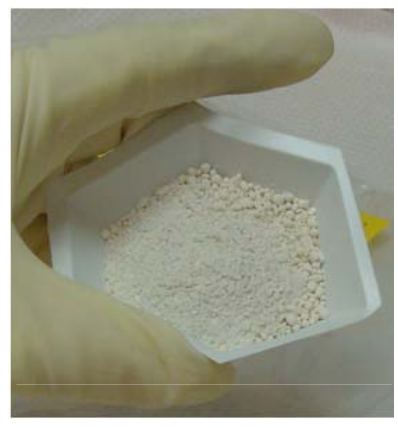

Figure 22. $\mathrm{MgO}$ collected from $\mathrm{R} 14 \mathrm{C} 2$.

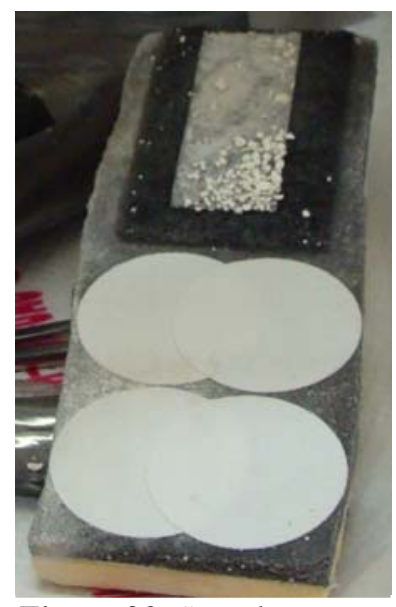

Figure 23. Sample collected from R16 C4 using Swiffer head. 
Two additional MgO samples were collected (August 15, 2014) from an intact bag of $\mathrm{MgO}$ located on the floor at the waste face (upstream from the event). One sample was taken at the MgO surface inside the bag and the other at a depth of 6 inches. Both samples were surveyed for radioactivity and were found to have less than 1.71E2 dpm/sample of Am-241. Finally, a sample of $\mathrm{MgO}$ that had not been placed in the mine (and was not radioactive) was collected from the WIPP site. This sample was used as a reference. All samples were white or beige colored and consisted of powder and pellets (see Figures 22-24). In R14 C6 and R14 C2, dark colored particles (4 and 1, respectively) were found (about 1-mm in diameter). They were physically separated and analyzed (see Figure 25).

4.2 Analytical Results: Specification for the MgO (Specification for Prepackaged MgO backfill: Specification D-0101 Revision 8, 02/11/09) to be emplaced in the underground areas at the WIPP states that "the sum of magnesium oxide $(\mathrm{MgO})$ plus calcium oxide $(\mathrm{CaO})$ shall be a minimum of $95 \%$, with the $\mathrm{MgO}$ being no less than 90\%.” Other materials that could be present in the $\mathrm{MgO}$ based on sample analysis (Attachment $\mathrm{D}$ to Specification document) include $\mathrm{SiO}_{2}, \mathrm{Al}_{2} \mathrm{O}_{3}$, and $\mathrm{Fe}_{2} \mathrm{O}_{3}$.

All MgO samples were analyzed by X-ray diffraction (XRD) and FTIR microscopy to determine if the $\mathrm{MgO}$ had reacted with water and/or $\mathrm{CO}_{2}$ to produce $\mathrm{Mg}(\mathrm{OH})_{2}, \mathrm{MgCO}_{3}$ and/or other metastable hydrous carbonates. [Xiong, 2008] X-ray diffraction pattern provides information mostly from the bulk sample while FTIR provides information about the surface of the sample. XRD patterns of the samples obtained from WIPP were compared to the reference MgO samples and search match identification was preformed with Jade software from Materials Data Inc. and the International Centre of Diffraction Database. FTIR spectra of the WIPP MgO samples were compared to reference spectra of potential reaction products (such as $\mathrm{Mg}(\mathrm{OH})_{2}$ and $\mathrm{MgCO}_{3}$ ) or from the literature. [Miller, 1952; Hanna, 1965; Kwon, 2009; Zhang, 2006] Since the samples contained both powder and pellets, as shown in Figures 22-24, both morphologies were independently examined by XRD. The X-ray diffraction patterns show the material from R14 and the two bags of MgO from Room 7 contained primarily $\mathrm{MgO}$ (see Figure 26 and 27) while extended analysis showed a small amount ( $<$ a few \%) of $\mathrm{CaCO}_{3}$ was present. No bulk $\mathrm{Mg}(\mathrm{OH})_{2}, \mathrm{MgCO}_{3}$ or other products from the reaction of $\mathrm{MgO}$ with $\mathrm{H}_{2} \mathrm{O}$ and/or $\mathrm{CO}_{2}$ were observed in the samples.

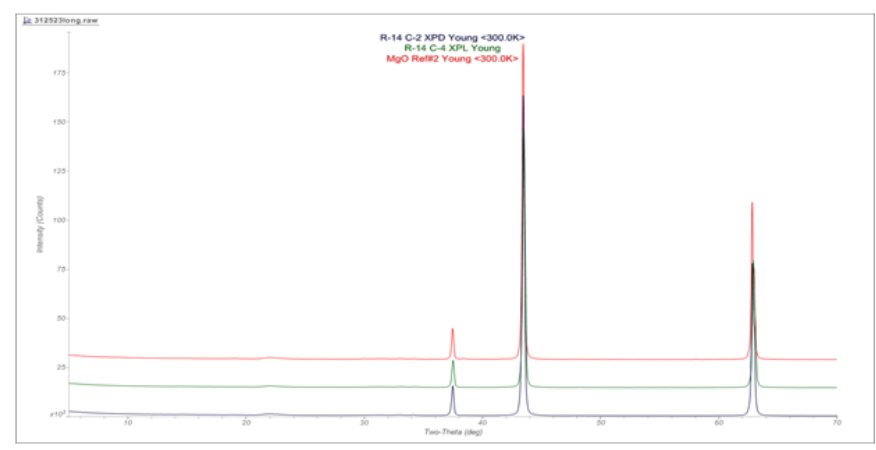

Figure 26. XRD of MgO from R14 C2, R14 C4 and a reference MgO sample. 


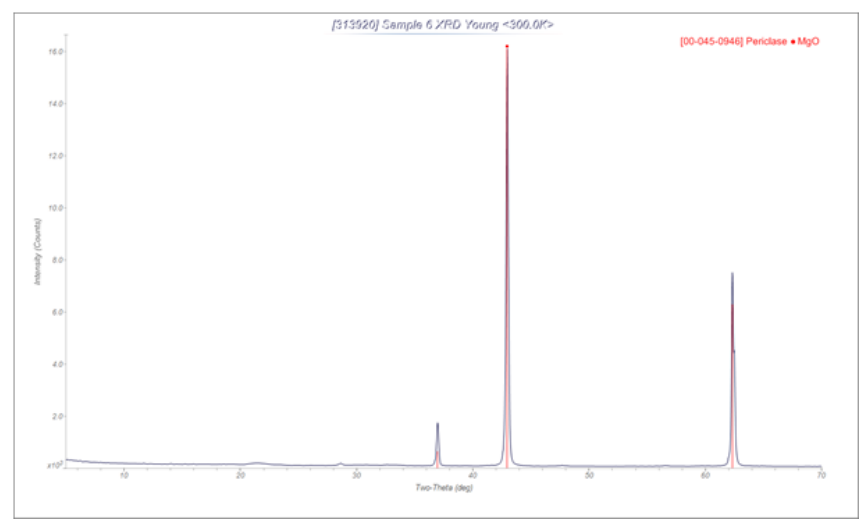

Figure 27. XRD of $M g O$ from super sack sampled at the surface.

FTIR microscopy showed the samples predominately contained MgO (see Figure 28 and 29). [Hanna, 1965] No OH stretches were observed at $3700 \mathrm{~cm}^{-1}$ (isolated $\mathrm{OH}$ ) and $3650-3350 \mathrm{~cm}^{-1}$ (H-bonded OH) for $\mathrm{Mg}(\mathrm{OH})_{2}$ [Kwon, 2009] and no strong $\mathrm{CO}_{2}$ stretches were observed at 1485 and $1420 \mathrm{~cm}^{-1}$ for $\mathrm{MgCO}_{3} \cdot 3 \mathrm{H}_{2} \mathrm{O}$. [Zhang, 2006] Samples from the surface of the sack in Room 7 showed small amounts of carbonates and silicates on the surface while samples taken from 6" deep had fewer surface species. Monodentate surface carbonates on MgO can be identified by stretches at 1510 - 1550, 1390 - 1410, 1035 - 1050, and 860 - $865 \mathrm{~cm}^{-1}$ while bicarbonates and bidentate carbonates show stretches at higher frequencies (1655-1670 $\left.\mathrm{cm}^{-1}\right)$. [Kwon, 2009] Silicates and magnesium silicates have stretches in the region from $1000-1300 \mathrm{~cm}^{-1}$. [Kalampounias, 2011] SEM-EDS analysis of the samples also showed $\mathrm{Mg}$, Ca and Si are present in the MgO. XRF analysis of the R14 MgO samples showed Fe, Ca with Ni, $\mathrm{Cr}$, Ti and $\mathrm{Zn}$ and trace amounts of $4 \mathrm{f}$ and $5 \mathrm{~d}$ elements (such as $\mathrm{Pb}$ ).

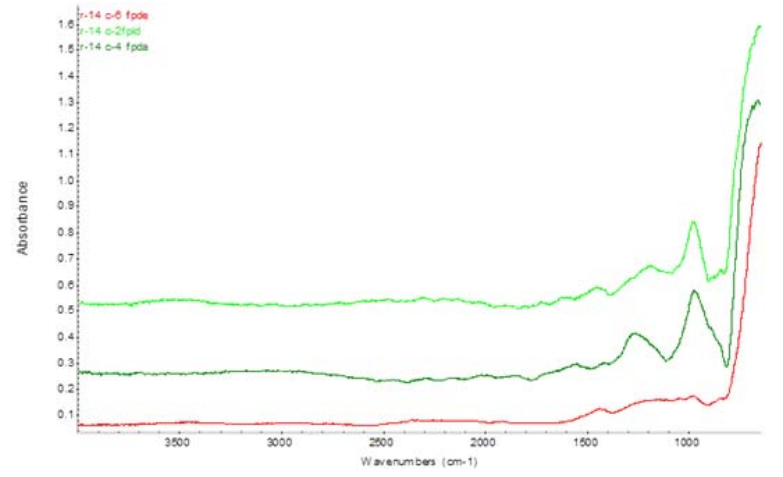

Figure 28. FTIR spectra from $\mathrm{MgO}$ from $\mathrm{R} 14 \mathrm{C} 2$, C4, and C6.

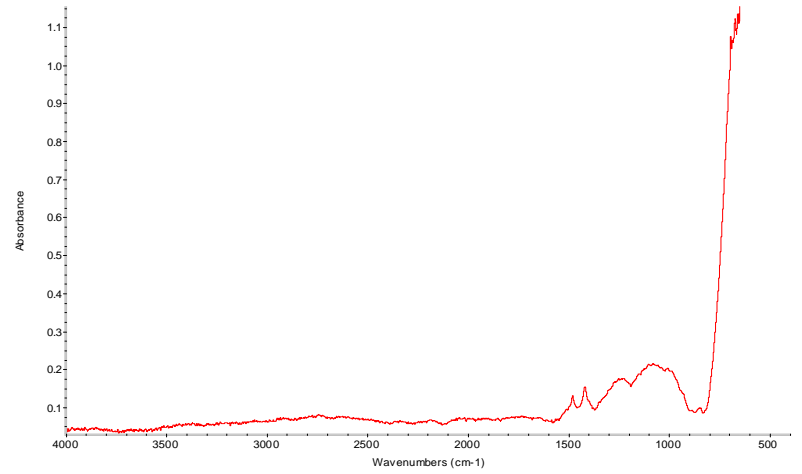

Figure 29. FTIR spectrum of $\mathrm{MgO}$ from sack at face of Panel 7 Room 7.

The dark colored particles in the R14 MgO samples were physically separated from the $\mathrm{MgO}$ and analyzed by FTIR and SEM-EDS. Similar dark particles were found in the reference MgO sample and the $\mathrm{MgO}$ specification indicate other material could be in the sample. SEM-EDS analysis showed elements including $\mathrm{Ti}, \mathrm{Si}, \mathrm{Al}, \mathrm{Fe}$, and $\mathrm{Mn}$ and FTIR analysis showed carbonates, sulfates, nitrates, iron oxide and silica were present.

Conclusion: Analysis of MgO samples obtained from Panel 7 Room 7 provided no evidence to support the presence of $\mathrm{Mg}(\mathrm{OH})_{2}, \mathrm{MgCO}_{3}$ or other metastable hydrous carbonate species that would be expected if the material in the super sacks was exposed to significant quantities of $\mathrm{CO}_{2}$ and/or $\mathrm{H}_{2} \mathrm{O}$ combustion products. Therefore it is concluded that the truck fire event did not cause the damage observed in Panel 7 Room 7. It is also concluded that the duration of the event was short which limited the radioactivity found on the $\mathrm{MgO}$ on the adjacent drums. 


\section{References}

Bensah, E. C.; Mensah, M. Chemical Pretreatment Methods for the Production of Cellulosic Ethanol: Technologies and Innovation. Int. J. Chem. Eng. 2013, Article ID 719607.

Bracuti, A. J. The Crystal and Molecular Structure of Triethanolammonium Nitrate. Technical Report ARAED-TR-92026; U. S. Army, December 1992.

Cembella, A. D.; Antia, N. J.; Taylor, F. J. R. The Determination of Total Phosphorous in Seawater by Nitrate Oxidation of the Organics Component. Wat. Res. 1986, 20, 1197-1199.

Chang, Y.-P.; Boyer, E.; Kuo, K. K. Combustion Behavior and Flame Structure of XM46 Liquid Propellant. J. Propulsion Power 2001, 17, 800-808.

Clark, D. L.; Funk, D. J. Waste Isolation Pilot Plant (WIPP): Chemical Reactivity and Recommended Remediation Strategy for Los Alamos Remediated Nitrate Salts (RNL) Waste, Los Alamos, NM. 2015. LA-CP-15-20082.

Costas, M. N.; Veigas, B.; Jacob, J. M.; Santos, D. S.; Gomes. J.; Baptista, P. V.; Martins, H.; Inácio, J.; Fortunato, F. Nanotech. 2014 25, 94006.

Cronin, J. T.; Brill, T. B. Thermal Decomposition of Energetic Materials 29- The Fast Thermal Decomposition of Characteristics of a Multicomponent Material: Liquid Gun Propellant 1845. Combust. Flame 1988, 74, 81-89.

Desai, D. H.; Patel, C. K.; Patel, K. C.; Patel, R. D. The Effect of Some Nitrate Salts on the Thermal Behaviour of Amylose. Die Stärke 1972, 42-45.

Fontana, J. D.; Mitchell, D. A.; Molina, O. E.; Gaitan, A.; Bonfim, T. M. B.; Adelmann, J.; Grzybowski, A.; Passos, M. Startch Depolymerization with Dilute Phosphoric Acid and Application of the Hydrolysate in Astazanthin Fermentation. Food Technol. Biotechnol. 2008, 46, 305-310.

Gadalla, A. M. M. Kinetics of the Decomposition of Hydrated Oxalates of Calcium and Magnesium in Air. Thermochimica Acta 1984, 74, 255-272.

Hammond, M. J. Reversible Liquid/Solid Phase Change Compositions. US Patent 5,785,884, July 28, 1998.

Hanna, R. Infrared Properties of Magnesium Oxide. J. Am. Chem. Soc. 1965, 48, 376-380.

Içbudak, H.; Yilmaz, V. T.; Ölmez, H. Thermal Decomposition Behavior of Some Trivalent Transition and Inner-Transition Metal Complexes of Triethanolamine. Thermochimica Acta 1996, 289, 23-32.

Janz, G. J.; Krebs, U.; Siegenthaler, H. F; Tomkins, R. P. T. Molten Salts: Volume 3, Nitrates, Nitrites and Mixtures. J. Phys. Chem. Ref. Data 1972, 1, 581-746.

Jung, Y. M. Characterization of pH-Dependent IR Spectra of Oxalic Acid: Comparison of Self-Modeling Curve Resolution Analysis with Calculation of IR Frequencies. Bull. Korean Chem. Soc. 2003, 24, 14101412.

Kalampounias, A. G. IR and Raman Spectroscopic Studies of Sol-Gel Derived Alkaline-Earth Silicate Glasses. Bull. Mater. Sci. 2011, 34, 299-303. 
Keely, W. M.; Maynor, H. W. Thermal Studies of Nickel, Cobalt, Iron, and Copper Oxides and Nitrates. J. Chem. Eng. Data 1963, 8, 297-300.

Kochkar, H.; Morawietz, M.; Hölderich, W. F. Appl. Catal. A. 2001, 210, 325-328.

Kozlowski, T. R.; Bartholomew, R. F. Reactions between Sodium Carboxylic Acids Salts and Molten Sodium Nitrate and Sodium Nitrite. Inorg. Chem. 1968, 7, 2247-2254.

Kwon, H.; Park, D. G. Infra-Red Study of Surface Carbonation of Polycrystalline Magnesium Hydroxide. Bull. Korean Chem. Soc. 2009, 30, 2567-2573.

Lambert, J. B.; Shurvell, H. F.; Cooks, R. G. Introduction to Organic Spectroscopy; Macmillan: New York, 1987; p 175.

Lapidus, G.; Barton, D.; Yankwich, P. E. Kinetics and Stoichiometry of the Gas-Phase Decomposition of Oxalic Acid. J. Phys. Chem. 1964, 68, 1863-1865.

Larmigny, J.-P.; Mathieu, J.-P.; Guerin, D.; Dobrowolski, A. Radiation attenuation elastomeric material, a multilayer glove for protection against ionizing radiation and their uses. US Patent 20120217423 A1; August 30. 2012.

Lee, Y. J.; Litzinger, T. A. Combustion Chemistry of HAN, TEAN, and XM46. Combustion Sci. Tech. 1999, 141, 19-36.

López-Lópeza, M.; Fernández de la Ossaa, M. A.; Galindoa, J. S.; Ferrando, J. L; Vega, A.; Torre, M; García-Ruiza, C. New Protocol for the Isolation of Nitrocellulose from Gunpowders: Utility in their Identification. Talanta 2010, 81, 1742-1749.

Magnuson, M. L.; Satzger, D.; Alcaraz, A.; Brewer, J.; Fetterolf, D.; Harper, M.; Hrynchuk, R.; Mcally, M. F.; Montgemery, M.; Nottingham, E.; Peterson, J.; Rickenbach, M.; Seidel, J. L.; Wolnik, K. Guidelines for the Identification of Unknown Samples for Laboratories Performing Forensic Analyses for Chemical Terrorism. J. Forensic Sci. 2012, 57, 636-642.

Martinez, P. T.; Chamberlin, R. M. Analytical Chemistry and Materials Characterization Results for Debris Recovered from Four Nitrate Salt Waste Drums. LANL, October 24, 2014.

Masoud, M. S.; Abou El-Enein, S. A.; Abed, I. M.; Ali, A. E. Synthesis and Characterization of Amino Alcohol Complexes. J. Coord. Chem. 2002, 55, 153-178.

Melnikov, P.; Nascimento, V. A.; Arkhangelsky, I. V.; Zanoni Consolo, L. Z. Thermal Decomposition Mechanism of Aluminum Nitrate Octahydrate and Characterization of Intermediate Products by the Technique of Computerized Modeling. J. Therm. Anal. Calorim. 2013, 111, 543-548.

Miller, F. A.; Wilkins, C. H. Infrared Spectra and Characteristic Frequencies of Inorganics Ions. Anal. Chem. 1952, 24, 1253-1294.

Moldoveanu, S. C. Analytical Pyrolysis of Natural Organic Polymers. Elsevier: Amsterdam, 1998; Chapter 12. Analytical Pyrolysis of Proteins, p 373- 396.

Naiini, A. A.; Young, Jr., V. G.; Verkade, J. G. Alkali and Alkaline Earth Metal Chloride Complexes of Triethanolamine: The Structure of [Sr(TEA) $\left.)_{2}\right]_{C l}$. Polyhedron 1997, 16, 2087-2092.

Ola, G.; Malhotra, R.; Narang, S. C. Nitration: Methods and Mechanisms. Wiley 1989. 
Oza, T. M.; Dipali, N. L. The Thermal Decomposition of Magnesium Nitrite. J. Indian Chem. Soc. 1950, 27, 305-316.

Pedersen, B. F. Interpretation of Infrared Spectra of Solid Alkali Metal Oxalates, and their Hydrates and Perhydrates. Acta Chemica Scandinavica 1967, 21, 801-811.

Rodríguez-Chong, A.; Ramírez, J. A.; Garrote, G.; Vazquez, M. Hydrolysis of Sugar Cane Bagasse using Nitric Acid: A Kinetic Assessment. J. Food Eng. 2004, 61, 143-152.

Sladek, J. H. Method for Sorbing Liquid Using Ground Wheat Grain Litter. U. S. Patent 5,690,052, November 25, 1997.

Socrates, G. Infrared Characteristic Group Frequencies; Wiley: West Sussex, England, 1994; p 54.

Smith, H. D.; Jones, E. O.; Schmidt, A. J.; Zacher, A. H.; Brown, M. D.; Elmore, M. R. Gano, S. R. Denitration of High Nitrate Salts Using Reductants. PNNL-12144, Pacific Northwest National Laboratory, Richland, Washington, 1999.

Sramkova, Z.; Gregova, E.; Sturdik, E. Chemical Composition and Nutritional Quality of Wheat Grain. Acta Chimica Slovaca 2009, 2, 115-138.

Stern, K. H. High Temperature Properties and Decomposition of Inorganic Salts Part 3. Nitrates and Nitrites. J. Phys. Chem. Ref. Data 1972, 1, 747-772.

Sullivan, J. M.; Williard, J. W.; White, D. L.; Kim, Y. K. Production of Oxalic Acid via the Nitric Acid Oxidation of Hardwood (Red Oak) Sawdust. Ind. Eng. Chem. Prod. Res. Dev. 1983, 22, 699-709.

Suppes, G. J.; Dasari, M. Synthesis and Evaluation of Alkyl Nitrates from Triglycerides as Cetane Improvers. Ind. Eng. Chem. Res. 2003, 42, 5042-5053.

Tipson, R. S. Infrared Spectroscopy of Carbohydrates. A Review of the Literature; National Bureau of Standards Monograph 110; U. S. Government Printing Office: Washington, DC, 1968.

Veazey, G. W.; Schake, A. R.; Shalke, P. D.; Romero, D. A.; Smith, C. A. Waste-form Development for Conversion to Portland Cement at Los Alamos National Laboratory (LANL) Technical Area 55 (TA-55), LA-13125 (1996)

Wieczorek-Ciurowa, K.; Kozak, A. J. The Thermal Decomposition of $\mathrm{Fe}\left(\mathrm{NO}_{3}\right)_{3} \cdot 9 \mathrm{H}_{2} \mathrm{O}$. J. Therm. Anal. Calorim. 1999, 58, 647-651.

Wu, K.-T.; Zavarin, E. Thermal Analysis of Mixtures of Nitrates and Lignocellulosics Materials. Thermochim. Acta 1986, 107, 131-148.

Würfels, W.; Jackwerth, E. Residues from Biological Materials after Pressure Decomposition with Nitric Acid. Anal. Chim. Acta 1989, 226, 1-16.

Xiong, Y.; Lord, A. S. Experimental Investigation of the Reaction Path in the MgO- $\mathrm{CO}_{2}-\mathrm{H}_{2} \mathrm{O}$ System in Solution with Various Ionic Strengths, and their Application to Nuclear Waste Isolation. Appl. Geochem. 2008, 23, 1634-1659.

Yilmaz, V. T.; Topcu, Y.; Karadag, A. Thermal Decompostion of Triethanolamine and Monoethanolethylenediamine Complexes of Some Transition Metal Saccharinates. Thermochim. Acta 2002, 383, 129-135. 
Zhang, Z.; Zheng, Y.; Ni, Y.; Liu, Z.; Chen, J.; Liang, X. Temperature- and pH-Dependent Morphology and FT-IR Analysis of Magnesium Carbonate Hydrates. J. Phys. Chem. B 2006, 110, 12969-12973. 